A R C HIWA, BIBLIOTEKI

I MUZEA KOŚCIELNE 111 (2019)

https://doi.org.10.31743/abmk.2019.111.13

ŁUKASZ PUŚLECKI* - PIASKI

\title{
NIEZNANY LIST EDMUNDA BOJANOWSKIEGO ZE ZBIORÓW PRYWATNYCH
}

\section{Streszczenie}

Autor artykułu podczas prowadzenia badań dotyczących dorobku naukowego E. Bojanowskiego natrafił przypadkowo na jego nieznany list z roku 1866. Treść korespondencji opatrzono szerokim komentarzem prezentującym jej kontekst historyczny. Przedstawiono przede wszystkim biografię odbiorcy listu - księdza Antoniego Śmitkowskiego. Przybliżono również współpracę założyciela służebniczek z fundatorką ochronki, której otwarcia dotyczy korespondencja - tj. z księżną Elżbietą z Działyńskich Czartoryską. Rozwinięto również wątek sposobu rekrutacji kandydatek do zgromadzenia służebniczek na przykładzie wspominanej w korespondencji Rozalii Krzekotowskiej.

Słowa kluczowe: Edmund Bojanowski; Elżbieta z Działyńskich Czartoryska; ks. Antoni Śmitkowski; korespondencja; ochronki wiejskie

\section{Wprowadzenie}

W obecnych czasach większość tekstów źródłowych, istotnych dla badań historycznych, została należycie zabezpieczona - są przechowywane, opracowane, zdygitalizowane, opublikowane. Stało się to staraniem wielu pokoleń pasjonatów przeszłości, historyków, archiwistów, muzealników, urzędników, instytucji państwowych i kościelnych. Jednak cały czas podczas prowadzenia badań historycy odkrywają ciekawe dokumenty, korespondencję. Adam Górski - badacz z Uniwersytetu Zielonogórskiego - wydając dokumenty uzyskane od kapłana $z$ terenu województwa lubuskiego, rozpoczął swój tekst od następującej refleksji uzasadniającej celowość upubliczniania tego typu odkryć:

* Łukasz Puślecki - dr historii; nauczyciel w Szkole Podstawowej z Oddziałami Integracyjnymi im. Mikołaja Kopernika w Piaskach, e-mail: lukaspuslecki@op.pl

https://orcid.org/0000-0001-7245-8131 
Prowadząc badania terenowe, historyk czasami natrafia na oryginalne dokumenty lub ich kopie znajdujące się w rękach osób prywatnych, które weszły w ich posiadanie w sposób przypadkowy. Ważne jest włączenie owych źródeł poprzez publikacje do obiegu naukowego, niosą one bowiem często informacje bardzo szczegółowe, a czasami wręcz unikalne ${ }^{1}$.

Autor prezentowanego tu listu - Edmund Bojanowski (1814-1871) - nie jest postacią powszechnie znaną, jednak jego działalność i dorobek - w kontekście historii i kultury Wielkopolski w XIX wieku, historii Kościoła katolickiego oraz katolickiej pedagogiki - zostały zauważone i docenione. Aktualnie prowadzone są badania poświęcone różnym aspektom jego działalności. Przez długie lata tematyka ta nie budziła jednak większego zainteresowania. Niebagatelną-zapewne wręcz kluczową - rolę w przypomnieniu, odkrywaniu dorobku E. Bojanowskiego odegrał jego, trwający długie lata, proces beatyfikacyjny, zakończony uroczystą beatyfikacją w 1999 roku. Badanie i popularyzację biografii E. Bojanowskiego rozpoczęli - z oczywistych względów - autorzy z kręgu Kościoła katolickiego. Siostry służebniczki - Agnieszka Szelęgiewicz i Maria Kornacka - opracowały dwie naukowe biografie założyciela swojego zgromadzenia ${ }^{2}$. Opublikowano też wiele opracowań popularyzatorskich ${ }^{3}$. Wraz z rozwojem kultu Sługi Bożego, a obecnie błogosławionego, powstało też mnóstwo książek o charakterze religijnym, teologicznym, duszpasterskim. Na wielu polskich uczelniach napisano imponującą ilość prac dyplomowych poświęconych E. Bojanowskiemu ${ }^{4}$. Odbyło się też kilka sympozjów naukowych, pokłosiem których były publikacje materiałów konferencyjnych ${ }^{5}$.

${ }^{1}$ A. Górski, Dokumenty z wieży kościoła w Przybymierzu, „Studia Zachodnie”, 8 (2006) s. 283.

${ }^{2}$ M. Kornacka, Edmund Bojanowski (1814-1871), „Nasza Przeszłość. Studia z dziejów Kościoła i kultury katolickiej w Polsce”, 26 (1967); A. Szelęgiewicz, Edmund Bojanowski i jego dzieło, Poznań-Warszawa-Lublin 1966. Warto pamiętać też o pierwszej, pośmiertnej biografii E. Bojanowskiego autorstwa ks. Antoniego Brzezińskiego (Wspomnienie o ś.p. Edmundzie Bojanowskim fundatorze Zgromadzenia Stużebniczek Bogarodzicy Dziewicy Niepokalanej, Poznań 1872).

${ }^{3}$ Spośród wielu tego typu prac szczególna uwaga należy się publikacji autorstwa ks. Mariana Fąki, wicepostulatora w procesie beatyfikacyjnym E. Bojanowskiego (Ziarno wrzucone w ziemię. Edmund Bojanowski (1814-1871). Założyciel Zgromadzenia Sióstr Stużebniczek N.M.P. Niepokalanie Poczętej, Wrocław 1988, wyd. 2 Poznań 1999). Najnowszym bodajże popularnym opracowaniem biografii E. Bojanowskiego jest książka autorstwa Tomasza P. Terlikowskiego (Edmund Bojanowski. Święty na nasze czasy, Warszawa 2015).

${ }^{4}$ Wyobrażenie o ilości opracowań i artykułów o tematyce religijnej oraz dotyczących E. Bojanowskiego prac dyplomowych - nie tylko, choć w większości - omawiających jego działalność i refleksję religijno-charytatywną, daje bibliografia przygotowana przez Stefana Jankowiaka (Edmund Bojanowski 1814-1871. Życie i działalność. Bibliografia, Grabonóg 1995). Od czasu ukazania się zestawienia bibliograficznego ilość tego typu publikacji znacznie się powiększyła.

${ }^{5}$ Stuga Boży Edmund Bojanowski apostot laikatu. Materiały z sympozjum, red. B. Zakrzewski, M.M. Szmidt, Warszawa 1990; Stuga Boży Edmund Bojanowski i jego troska o człowieka. Materiaty z II sympozjum, Grabonóg 1991; Błogosławiony Edmund Bojanowski. Serdecznie dobry człowiek, red. S. Wilk, Lublin 2000; Stużyć i wychowywać do miłości. Błogosławiony Edmund Bojanowskiwychowawca i apostol laikatu, red. M.L. Opiela, A. Smagacz, S. Wilk, Lublin 2009. 
Badania dotyczące wybranych aspektów dorobku E. Bojanowskiego rozpoczęli również $\mathrm{w}$ pewnym momencie świeccy autorzy, głównie historycy i poloniści. Doceniono bowiem znaczącą rolę, jaką odegrał on w realizacji programu pracy organicznej oraz odkryto, zapomniane niemal całkowicie, jego osiągnięcia literackie i naukowe. Działalność organicznikowską E. Bojanowskiego przypomniał poznański historyk, Witold Jakóbczyk, w swojej klasycznej już dziś monografii, ponadto umieścił on przedruk jednego z jego artykułów w wyborze źródeł do dziejów Wielkopolski oraz opracował biogram w Wielkopolskim stowniku biograficznym ${ }^{6}$. Autor ten odwoływał się do tekstów E. Bojanowskiego publikowanych na łamach leszczyńskiego „Przyjaciela Ludu", choć w zakresie interesujacej go problematyki - czyli zagadnień oświaty ludowej - wiele ciekawego materiału znajduje się w Dzienniku i korespondencji założyciela służebniczek. Przez długie lata był to jednak jedyny przykład zajęcia się dorobkiem E. Bojanowskiego przez zawodowych historyków (świeckich badaczy uniwersyteckich). Przyczyn tego stanu rzeczy, tj. znikomej obecności E. Bojanowskiego w badaniach historyków zajmujących się dziejami Wielkopolski w XIX wieku, było zapewne kilka. W dużej mierze zaważyły na tym specyficzne realia, w jakich funkcjonowała nauka w czasach Polskiej Rzeczpospolitej Ludowej. Osoba działacza społecznego o pochodzeniu ziemiańskim, dość powszechnie kojarzonego z Kościołem katolickim i środowiskiem konserwatywno-katolickim (tzw. ultramontanie) nie mogła - choćby na to zasługiwała - stać się obiektem wszechstronnych badań $w$ tamtych czasach. Należy jednak zwrócić uwagę, że nieuwzględnianie tekstów pozostałych po E. Bojanowskim w badaniach dotyczących dziejów Wielkopolski w XIX wieku miało też swoją obiektywną przyczynę, polegającą na ich niedostępności. Znajdowały się one w archiwum sióstr służebniczek w Dębicy, ewentualnie w formie maszynopisowych odpisów w innych większych placówkach zgromadzenia. O tym, jaką wartość przedstawiają one dla badań historycznych (zresztą nie tylko historycznych), przekonano się, gdy zaczęto wydawać drukowane edycje spuścizny źródłowej E. Bojanowskiego. Z inicjatywą tą wystąpiło Zgromadzenie Sióstr Służebniczek. Pomijając mniejsze publikacje o tematyce typowo religijnej, będące tematycznymi zestawieniami cytatów z pism E. Bojanowskiego, należy zwrócić uwagę na wydanie wyboru jego Dziennika, przygotowane przez Amelię i Tadeusza Szafrańskich ${ }^{7}$. Tekst ten mógł trafić odtąd do szerszego grona odbiorców. Zaczął być też uwzględniany jako źródło - nie tylko w wydanej, ale też całościowej rękopiśmiennej wersji $\mathrm{w}$ pracach historycznych ${ }^{8}$. Wspomniana edycja była jednak tylko wyborem

${ }^{6}$ W. Jakóbczyk, Studia nad dziejami Wielkopolski w XIX w. (Dzieje pracy organicznej), t. 1: 1815-1850, Poznań 1951; Wielkopolska (1815-1850). Wybór źródet, oprac. W. Jakóbczyk, Wrocław 1952; W. Jakóbczyk, Bojanowski Edmund (1814-1871), w: Wielkopolski stownik biograficzny, red. A Gąsiorowski, Warszawa-Poznań 1981, s. 67-68.

${ }^{7}$ E. Bojanowski, Dziennik 1853-1871, wybór, wstęp i przypisy A. i T. Szafrańscy, Warszawa 1988 (wyd. 2 Warszawa 1999).

${ }^{8}$ Należy tu przede wszystkim wskazać na opracowania autorstwa Stefana Jankowiaka (Kasyno Gostyńskie (1835-1846). U początków pracy organicznej w Wielkopolsce, Gostyń 1996) i Przemysława Matusika (Religia i naród. Życie i myśl Jana Koźmiana 1814-1877, Poznań 1998). 
bardzo obszernego Dziennika. Wraz z rosnącym zainteresowaniem osobą E. Bojanowskiego podjęto niełatwy i pracochłonny projekt wydania całości jego rękopiśmiennej spuścizny źródłowej. Jej opracowaniem zajął się Leonard Smołka - historyk i archiwista z Uniwersytetu Wrocławskiego. Zadanie to wykonał bardzo rzetelnie, opatrując tekst szczegółowym komentarzem w postaci przypisów, umożliwiającym czytelnikom dostrzeżenie szerszego kontekstu działalności E. Bojanowskiego, uczonym zaś ułatwiającym wykorzystanie jego rękopiśmiennej spuścizny we własnych badaniach. W 2001 roku ukazała się $\mathrm{w}$ dwóch tomach całość korespondencji E. Bojanowskiego ${ }^{9}$. Natomiast w 2009 roku publikacji doczekał się pełny tekst Dziennika, który zajął cztery obszerne tomy $^{10}$. Edycja listów E. Bojanowskiego została przychylnie przyjęta przez znanego badacza dziejów XIX-wiecznej Wielkopolski - Witolda Molika z Uniwersytetu im. Adama Mickiewicza w Poznaniu. W swojej recenzji podkreślił on, że wydane przez L. Smołkę dwa tomy korespondencji E. Bojanowskiego „,[...] uznać należy za duże osiągnięcie edytorskie i zarazem za dzieło wyróżniające się pod wieloma względami na tle podobnych wydawnictw"11.

Przechodząc do zagadnienia poznawczej wartości korespondencji E. Bojanowskiego i jej przydatności do badań naukowych, warto przytoczyć refleksję L. Smołki. Był on przekonany, że wydanie całości korespondencji założyciela służebniczek sprawi, iż stanie się ona źródłem, do którego coraz częściej odwoływać się będą historycy, pedagodzy, psycholodzy, badacze kultury, etnografowie, religioznawcy, teolodzy, eklezjaści ${ }^{12}$. Do tej pory bowiem - głównie ze względu na trudność dostępu do jej treści - korzystali z niej prawie wyłącznie autorzy zajmujący się badaniem biografii i dorobku E. Bojanowskiego. Natomiast opublikowanie wszystkich jego listów zachowanych w dębickim archiwum stwarza „(...) możliwość wykorzystania ich treści w badaniach, które nie muszą być związane bezpośrednio ani z Bojanowskim, ani z założonym przez niego zgromadzeniem" "' Jak się później okazało, stwierdzenie to nie było bezpodstawne. Można bowiem podać przykłady poważnych monograficznych opracowań, które w żaden sposób bezpośrednio nie dotyczą E. Bojanowskiego i jego działalności, a których autorzy korzystali w swoich badaniach z wydanych w 2001 i 2009 roku korespondencji i Dziennika założyciela służebniczek. Chodzi tu o powstałe w UAM w Poznaniu dzieła autorstwa Aliny Hinc i Przemysława Matusika ${ }^{14}$.

${ }^{9}$ Korespondencja Edmunda Bojanowskiego z lat 1829-1871, t. 1: Listy Edmunda Bojanowskiego z lat 1836-1871, t. 2: Listy do Edmunda Bojanowskiego z lat 1829-1868, objaśnił, skomentował i zarysem monograficznym poprzedził L. Smołka, Wrocław 2001.

${ }^{10}$ E. Bojanowski, Dziennik, wydanie kompletne rękopisu i luźnych kartek Dziennika wraz z zapisami dziennymi Ochronka Podrzecka 1851-1854 i relacją s. Elżbiety Szkudłapskiej Ostatnie dnie życia i pogrzeb, objaśnił, skomentował i wstępem poprzedził L. Smołka, t. 1-4, Wrocław 2009.

${ }^{11}$ W. Molik, (rec.) Korespondencja bt. Edmunda Bojanowskiego, „Kronika Wielkopolski”, (2003) nr 1, s. 119.

${ }_{12}$ Smołka, Edmund Bojanowski i jego korespondencja z lat 1829-1871, w: Korespondencja, t. 1 , s. 96 .

${ }^{13}$ Smołka, Edmund Bojanowski, s. 96.

${ }^{14}$ A. Hinc, Obraz dziejów ojczystych w pozaszkolnej edukacji historycznej spoleczeństwa polskiego w Wielkim Księstwie Poznańskim w pierwszej połowie XIX wieku, Poznań 2007, s. 73-74, 
Ostatnio wydana została dotąd nieopublikowana część spuścizny źródłowej po E. Bojanowskim. Jest to zbiór jego luźnych notatek. Edycja ta przygotowana została przez badaczy z Katolickiego Uniwersytetu Lubelskiego ${ }^{15}$. Ukazanie się kolejnego, gruntownie opracowanego wydawnictwa źródłowego będzie skutkować zapewne podejmowaniem nowych badań nad dorobkiem E. Bojanowskiego oraz wykorzystywaniem jego tekstów w pracach dotyczących różnych dziedzin szeroko pojętej humanistyki.

Poza zasygnalizowaną wyżej coraz szerszą recepcją pism E. Bojanowskiego w pracach traktujących o dziejach Wielkopolski w XIX wieku, należy zwrócić uwagę na ważny nurt badań nad - do pewnego momentu zapomnianą, a czasem nieco lekceważoną - jego działalnością literacko-naukową. Prekursorem był tutaj historyk literatury z Uniwersytetu Wrocławskiego - Bogdan Zakrzewski ${ }^{16}$. Późniejsze studia w tym zakresie prowadzili językoznawcy - głównie Krzysztof Maćkowiak i Bogdan Walczak ${ }^{17}$. Zbliżoną tematyką - tj. regionalnymi badaniami historycznymi i folklorystycznymi E. Bojanowskiego - zajmuje się także piszący te słowa ${ }^{18}$.

Ostatnio najbardziej dynamicznie rozwijają się badania nad dorobkiem E. Bojanowskiego w zakresie pedagogiki. Dotyczą one sformułowanego przez niego oryginalnego programu wychowania ijego funkcjonowania w prowadzonych przez służebniczki ochronkach. Ilość poświęconych tym zagadnieniom opracowań jest imponująca ${ }^{19}$.

Powyższy, bynajmniej niewyczerpujący, przegląd literatury i kierunków badań nad dorobkiem E. Bojanowskiego oraz refleksji nad znaczeniem źródłowych edycji jego tekstów przekonuje o tym, że temat ten w różnych aspektach-zarazem religijnych, jak i świeckich - nie jest zamknięty, lecz żyje, jest wciąż aktualny, intensywnie badany.

340-341, 479; P. Matusik, „Nadeszła epoka przejścia...” Nowoczesność w piśmiennictwie katolickim Poznańskiego 1836-1871, Poznań 2011, s. 35, 61, 168.

${ }^{15}$ Prace, szkice i notatki Edmunda Bojanowskiego. Inedita, red. E. Gigilewicz, M.L. Opiela, t. 1-2, Lublin 2016.

${ }^{16}$ Autor ten poświęcił E. Bojanowskiemu kilkanaście artykułów i fragmentów większych opracowań. Dotyczyły one głównie tematyki jego działalności wydawniczej (zob. np. Norwid w „Pokłosiu” Edmunda Bojanowskiego, „Pamiętnik Literacki”, 50 (1959) z. 2) oraz zbieractwa folklorystycznego (zob. np. Ślaska pieśń ludowa w zbiorach z okresu romantyzmu, Wrocław 1962).

${ }^{17}$ Zob. np. K. Maćkowiak, B. Walczak, Język i styl w kręgu zainteresowań Edmunda Bojanowskiego, Poznań-Zielona Góra-Grabonóg 2001; K. Maćkowiak, Edmunda Bojanowskiego fascynacje językiem narodowym, ,Język Polski”, 88 (2008) nr 4-5, s. 266-279; B. Walczak, M. Witaszek-Samborska, O zbiorku „prowincjonalizmów” wielkopolskich Edmunda Bojanowskiego, „Studia z Filologii Polskiej i Słowiańskiej", 30 (1993) s. 91-101.

${ }^{18}$ Zob. np. Ł. Puślecki, Fascynacja i edukacja. Program badań folklorystycznych Edmunda Bojanowskiego jako system wymiany intelektualnej, w: Dziedzictwo myśli pedagogicznej Edmunda Bojanowskiego we wspótczesnej edukacji w Polsce i na świecie, red. M.L. Opiela, Lublin 2014, s. 133-155; Ł. Puślecki, Edmund Bojanowski jako badacz historii regionu, „Zeszyty Naukowe KUL", (2017) nr 4, s. 63-93.

${ }^{19} \mathrm{~W}$ tym nurcie badawczym należy zwrócić uwagę na kilkadziesiąt artykułów i opracowań autorstwa siostry Marii Loyoli Opieli, przede wszystkim na rozprawę Integralna pedagogika przedszkolna w systemie wychowania Edmunda Bojanowskiego. Kontynuacja i zmiana, Lublin 2013. 
Niniejsza edycja będzie zapewne ważna dla zainteresowanych religijnym, ochronkowo-zakonnym aspektem działalności E. Bojanowskiego. Prezentowany tu list nie zawiera jakichś wyjątkowo odkrywczych treści poznawczych, jednak wpisując się w całość wydanej korespondencji, uzupełnia jej przekaz i niesie w sobie informacje, które mogą być pożyteczne dla badaczy określonych zagadnień. Tekst ten dotyczy tematyki ochronkowej. Ochronki wiejskie były swoistym opus vitae E. Bojanowskiego. Tak są też postrzegane w ogólnym wizerunku tej postaci utrwalonym w świadomości potomnych. Rozwój sieci ochronek i tworzenie prowadzącego je zgromadzenia zakonnego pochłonęły cały niemalże czas i stopniowo zdominowały inną aktywność E. Bojanowskiego od 1850 roku. List może być kolejnym świadectwem sposobu tworzenia i zarządzania ochronkowym dziełem. Pojawiają się w nim daty inauguracji działalności konkretnych ochronek oraz informacje o planach otwierania kolejnych. Mowa jest także o datach rekolekcji dla służebniczek z diecezji poznańskiej i gnieźnieńskiej. Uzupełnia to i potwierdza informacje pojawiające się w korespondencji i Dzienniku E. Bojanowskiego z roku 1866. Ponadto list jest przykładem znanej z pozostałych źródeł praktyki powstawania ochronek w ścisłym współdziałaniu z lokalnym duchowieństwem i dworami ziemiańskimi. Dzieje placówki, której otwarcie jest tematem prezentowanej korespondencji, świadczą też o specyficznych, często niełatwych, relacjach finansowych między założycielem ochronek a ziemiańskimi fundatorami, a także o sposobie przyjmowania kandydatek do zgromadzenia poprzez zasięganie opinii duszpasterzy z parafii ich pochodzenia oraz dużej roli założyciela $\mathrm{w}$ całym procesie rekrutacji i formacji przyszłych służebniczek. Pojawiające się w liście informacje mogą mieć też znaczenie dla badaczy historii regionu, którego on dotyczy - tj. Jutrosina i okolic. 
N.B.P.J.Ch. ${ }^{21}$

\section{Tekst listu ${ }^{20}$}

Szanowny Księże Dziekanie Dobrodzieju!

Łaskawy list Szanownego Księdza Dziekana Dobrodzieja z d. 22. t. m. odebrałem przez jadącą do Jaszkowa kandydatkę Rozalią Krzekotowską i przyjęcie téjże ${ }^{22}$ do nowicjatu, poleciłem Siostrom.

Serdecznie cieszę się zarazem że podług życzenia Księżnéj będziemy mogli wkrótce dać Siostry do Ochronki w Rogozewie, gdyż Karmińską Ochronkę, w skutek porozumienia się z P. Stan. Sczanieckim odłożemy na późniéj, a Siostry tam obiecane przeznaczemy do Rogozewa. -

Rekollekcye zaś Sióstr w tutéjszéj Dyecezyi odbyły się już w zeszłym tygodniu a Gnieźnieńskie zakończą się 1. Grudnia poczem nastąpi otwarcie Ochronki w Lewkowie pod Ostrowem, 8. Grudnia; zatem chcielibyśmy w trzecią niedzielę Adwentu 16. Grudnia zaprowadzić Siostry w Rogozewie. Gdyby jednak dzień ten nie był dogodnym Szanownemu Księdzu Dziekanowi Dobrodziejowi, tobyśmy prosili o wczesne uwiadomienie.

Ja także, jeśli mi Pan Bóg pozwoli starać się będę przybyć na otwarcie Ochronki Rogozewskiéj, aby osobiście polecić Siostry najłaskawszéj Opiece Szanownego Księdza Dziekana Dobrodz. i złożyć Mu moje głębokie uszanowanie, z którem zostaję

Grabonóg

27. Listopada

najniższym w Ch.P. sługą

1866. r.

$$
\text { Jego }
$$

E. Bojanowski ${ }^{23}$

${ }^{20}$ Warto zwrócić uwagę, że w lewym górnym rogu rękopisu znajduje się obiekt, który zdaje się być odciskiem suchej pieczęci. Ma on formę liter otoczonych promieniami. Znak jest nieczytelny. Nic nie wskazuje na to, aby został on umieszczony na papierze przez E. Bojanowskiego. Na rękopisach innych jego listów przechowywanych w Dębicy obiekty takie występują zaledwie kilkukrotnie i wyraźnie różnią od tutaj opisywanego (informacja od siostry Agnieszki Skrzypek). Prawdopodobnie E. Bojanowski czasem posługiwał się papierem korespondencyjnym pozyskanym z księgarni lub od wydawców, z którymi współpracował i na arkuszach tych bywały umieszczone tego typu oznaczenia.

${ }^{21}$ N.B.P.J.Ch. to skrót religijnego pozdrowienia „Niech Będzie Pochwalony Jezus Chrystus”. E. Bojanowski bardzo często od tych słów rozpoczynał swoje listy, szczególnie te adresowane do sióstr służebniczek i księży. Kilka razy użył też języka kościoła (łaciny), posługując się skrótem L.J.Ch. (Laudetur Jesus Christus).

${ }^{22}$ Traktując prezentowany list jako źródło historyczne, zachowujemy w niniejszym przedruku oryginalne właściwości przekazu.

${ }^{23}$ W Dzienniku E. Bojanowski zwykł rejestrować swoją korespondencję, niekiedy także ją streszczając. Na temat niniejszego listu zapisał dnia 27 listopada 1866 r.: „Do ks. Smitkowskiego w Jutrosinie, odpis na list z 22 t. m. i że Ochronkę w Rogożewie chcemy otworzyć 16 grudnia. Ja także chcę przybyć" (t. 3, s. 769). 


\section{Losy rękopisu w relacji jego posiadacza}

Po śmierci jednego z proboszczów Parafii pod wezwaniem św. Elżbiety w Jutrosinie następca przeprowadził prace porządkowe, wyrzucając zalegające starocie. Wszelkie papiery i dokumenty trafiły do kotłowni, gdzie miały zostać spalone. Jeden z ówczesnych ministrantów zauważył list leżący wśród papierów i przyniósł go mnie, znając moje zainteresowania regionalnohistoryczne ${ }^{24}$.

\section{Adresat korespondencji}

W tekście listu adresat nie został zidentyfikowany z imienia i nazwiska. Wiadomo tylko, że był to jakiś ksiądz dziekan. Jego personalia łatwo można jednak ustalić poprzez konfrontację z pozostałą korespondencją E. Bojanowskiego. Rozpoczął on bowiem swoją wypowiedź od stwierdzenia, że prezentowany tu list jest odpowiedzią na pismo z dnia 22 listopada 1866 roku. Zachowało się ono $\mathrm{w}$ archiwum dębickim i zostało wydane w edycji L. Smołki. Jego nadawcą był ks. Antoni Śmitkowski z Jutrosina ${ }^{25}$.

Antoni Śmitkowski urodził się 1 czerwca 1820 roku w Zaniemyślu jako syn Teodora Śmitkowskiego i Elżbiety z domu Roszkiewicz ${ }^{26}$. Ochrzczony został jeszcze tego samego dnia ${ }^{27}$. Pierwsze nauki pobierał w szkole miejskiej w Zaniemyślu, następnie zaś uczęszczał do znanego poznańskiego Gimnazjum św. Marii Magdaleny, które ukończył zdaniem egzaminu dojrzałości w 1843 roku $^{28}$.

\footnotetext{
${ }^{24}$ Przedrukowany tu list znajduje się w zbiorach prywatnych Pana Ireneusza Mikołajewskiego z Jutrosina. Piszący te słowa pragnie serdecznie podziękować Panu Ireneuszowi za udostępnienie mu skanu listu oraz za przekazaną relację na temat historii tego rękopisu. Warto nadmienić, że Pan I. Mikołajewski jest kustoszem regionalnego muzeum w Jutrosinie. Wypada zatem zachęcić wszystkich podróżujących szlakiem E. Bojanowskiego i odwiedzających przy tej okazji Płaczkowo (dworek, w którym mieszkał Bojanowski) do zwiedzenia pobliskiego Jutrosina, gdzie Pan Ireneusz chętnie zaprezentuje zbiory muzeum oraz oprowadzi po imponującym neoromańskim kościele pw. św. Elżbiety.

${ }^{25}$ List ks. Antoniego Śmitkowskiego do E. Bojanowskiego z 22.11.[18]66, w: Korespondencja, t. 2, s. 531. W wydaniu Dziennika E. Bojanowskiego pisownia nazwiska tego kapłana występuje w formie „Smitkowski”, natomiast w korespondencji „Szmitkowski”. W przywołanych niżej materiałach archiwalnych dominuje wersja „Smitkowski”. W elenchusach także niekonsekwentnie stosowano pisownię nazwiska tego kapłana - najpierw przez „S”, potem „Sz”, a od 1864 roku przez „Ś. W niniejszym artykule przyjmujemy tę ostatnią wersję.

${ }^{26}$ Archiwum Archidiecezjalne w Poznaniu (dalej: AAP), Akta Konsystorza Generalnego Arcybiskupiego Poznańskiego, sygn. KA 1061, Personalia kleryka Antoniego Smitkowskiego: Życiorys.

${ }^{27}$ AAP, KA 1061, wypis z księgi chrztów parafii Zaniemyśl sporządzony 14 grudnia $1843 \mathrm{r}$.

${ }^{28}$ AAP, KA 1061, Życiorys, Świadectwo dojrzałości (Zeugniss der Reife den Zöglig des Königlichen Marien-Gymnasiums in Posen). W świadectwie dojrzałości, wystawionym 20 września 1843 roku, podano, że A. Smitkowski 9 lat uczęszczał do gimnazjum, w tym 2 lata do klasy pierwszej. Zob. też Absolwenci Gimnazjum i Liceum Świętej Marii Magdaleny w Poznaniu 1805-1950, oprac. A. Białobłocki, Poznań 1995, s. 131.
} 
Dnia 6 października tegoż roku zwrócił się z podaniem do księdza administratora poznańskiego seminarium duchownego z prośbą o przyjęcie do grona alumnów ${ }^{29}$. Został przyjęty do seminarium i po 5-letnich studiach i formacji w 1847 roku wyświęcony na kapłana ${ }^{30}$.

Pierwszym miejscem posługi ks. A. Śmitkowskiego jako wikarego była parafia w Wieleniu (koło Piły, ówczesny dekanat czarnkowski, dzisiejszy wieleński) ${ }^{31}$. Spędził tam dwa lata, następnie - w 1849 roku - został przeniesiony do Świerczyny (koło Leszna, ówczesny dekanat śremski, dzisiejszy krzywiński) ${ }^{32}$. W parafii tej był wówczas vacat na stanowisku proboszcza, a ks. A. Śmitkowski zapisany jest w elenchusach jako wikariusz w Świerczynie. Od 1853 roku określono go w kolejnych schematyzmach skrótem „Com.” (komendarz - administrator, zarządca) $)^{33}$. W 1854 roku w korespondencji ks. Śmitkowskiego z konsystorzem wielokrotnie poruszany był temat jego problemów zdrowotnych (przeszedł zapalenie płuc, lekarze zalecali wyjazd na kurację do wód, na którą, po ustaleniu zastępstwa w parafii i uzyskaniu paszportu, udał się w lipcu 1854 roku) ${ }^{34}$. W czasie posługi ks. A. Śmitkowskiego w Świerczynie miał miejsce pewien incydent, którego efektem była skarga skierowana do konsystorza. Pewien zarządca dóbr w Górznie (podpis nieczytelny) poczuł się dotknięty zachowaniem księdza, który w czasie nabożeństwa nakazał mu, za pośrednictwem kościelnego, opuszczenie zajmowanej przez niego pierwszej ławki w kościele. Człowiek ów poczuł się tą uczynioną publicznie uwagą tak dotknięty, iż opuścił kościół i wróciwszy do domu, napisał bardzo emocjonalny donos na księdza, opatrzony datą 11 maja 1856 roku. Konsystorz wystosował w tej sprawie pismo do dziekana dekanatu śremskiego ks. Jana Koperskiego z Dolska - polecając mu wyjaśnienie tej kwestii. Ks. A. Śmitkowski został wezwany do dziekana i na probostwie dolskim dnia 1 lipca 1856 roku sporządził odpowiedź przedstawiającą jego wersję wydarzeńn ${ }^{35}$.

W 1857 r. ks. A. Śmitkowski został przeniesiony do parafii Mokronos (koło Koźmina Wielkopolskiego, ówczesny dekanat koźmiński archidiecezji poznańskiej, dziś diecezja kaliska, dekanat koźmiński). Decyzja o przeniesieniu zapadła prawdopodobnie w początkowych miesiącach 1857 roku, skoro elenchus

${ }^{29}$ Kandydat deklarował, iż „czując w sobie od najpierwszej młodości szczerą chęć poświęcenia się stanowi duchownemu (...) wszelkiej siły dołożę, aby się na zdatnego robotnika w winnicy pańskiej wykształcić" - AAP, KA 1061, Podanie.

${ }^{30}$ Daty święceń każdego z wymienianych kapłanów podane są w elenchusach (rocznikach statystycznych diecezji, wydawanych corocznie jako załącznik do rubryceli liturgicznych). Datę tę potwierdza też dokument uprawniający ks. A. Śmitkowskiego do słuchania spowiedzi. Został od wystawiony 17 lipca 1847 roku dla „neoprezbytero” na „unus anni”- AAP, KA 1061.

${ }^{31}$ Elenchus universi cleri Archidioec. Posnaniensis pro Anno Domini 1848, w: Ordo Officii Divini ad usum Almae Eccles. Metropolitanae et Archi-Dioec. Posnaniensis pro Anno Domini MDCCCXLIII..., s. 48.

${ }^{32}$ Elenchus universi cleri...1850, s. 65.

${ }^{33}$ Elenchus universi cleri...1853, s. 61.

${ }^{34}$ AAP, KA 1061 . W elenchusie z tego roku w parafii świerczyńskiej wymieniony został rezydujący tam ksiądz emeryt Piotr Dykiert, którego obecność wiązała się prawdopodobnie z koniecznością zastąpienia chorującego ks. A. Śmitkowskiego - Elenchus universi cleri...1854, s. 62.

${ }^{35}$ AAP, KA 1061. 
na ten rok wymienia go jeszcze jako komendarza w Świerczynie ${ }^{36}$. Pierwsze pismo ks. A. Śmitkowskiego wysłane do konsystorza z Mokronosu opatrzone jest data $28 \mathrm{kwietnia} 1857 \mathrm{roku}^{37}$. Dotyczyło ono kwestii zdania egzaminu wymaganego dla uzyskania aprobaty do słuchania spowiedzi. Warto nadmienić, że korespondencja między duchownym a konsystorzem, dotycząca zdawania tych egzaminów (examen pro facultate ad excipiendas confesiones), zajmuje znaczącą część teczki personalnej. Dzięki niej można - jak się okazuje - doprecyzować informacje biograficzne. Prawo słuchania spowiedzi (obowiązujące zazwyczaj od jednego do dwóch lat) było uzależnione od przyjazdu do Poznania i zdania egzaminu z teologii. Ks. A. Śmitkowski, jak zdaje się wynikać z korespondencji, spełniał ten obowiązek bez nadmiernego entuzjazmu - zdarzało mu się nie dotrzymywać terminów, bywał dopytywany i ponaglany przez konsystorz, nieraz w bardzo stanowczych słowach. Często prosił on też o możliwość zdania wymaganego egzaminu nie w Poznaniu, ale na miejscu, u lokalnego księdza dziekana. Powoływał się wówczas na względy duszpasterskie (w czasie epidemii cholery nie chciał opuszczać parafii na kilka dni ze względu na konieczność ciągłych wizyt z sakramentami u chorych i umierających). Konsystorz wielokrotnie wyrażał na to zgodę ${ }^{38}$. W czasie posługi ks. A. Smitkowskiego w Mokronosie miała miejsce pewna dziwna historia z donosami parafian do konsystorza. Dotyczyły one spraw natury obyczajowej. Nie odnosiły się jednak do księdza, a do jego siostry, będącej gosposią na plebani. $Z$ donosów wynikało, że siostra ks. A. Śmitkowskiego, która była panną, utrzymywała dość zażyłe kontakty z pewnym mężczyzną, organistą w mokronoskiej parafii. Nie byłoby w tym nic wybitnie zdrożnego, gdyby nie fakt, że człowiek ów był żonaty. Sytuacja ta miała gorszyć parafian. Lektura donosu przekonuje, że jego autorem był przedstawiciel społeczności wiejskiej (tekst pełen błędów i niezręczności językowych, specyficzny charakter pisma). Ks. A. Śmitkowski wystosował odpowiedź na te zarzuty, podważając wiarygodność opisanych w donosie sytuacji i przywołanych świadków. Pisma dotyczące tej sprawy zamykają się w przedziale czasowym sierpień-październik 1858 roku $^{39}$.

Następną placówką, w której (od 27 września 1860 roku) pełnił posługę ks. A. Śmitkowski był Jutrosin (między Krotoszynem a Rawiczem, ówczesny dekanat krobski, dziś jutrosiński) ${ }^{40}$. Początkowo był on komendarzem parafii, a od 1863

${ }^{36}$ Elenchus universi cleri...1857, s. 28. W elenchusie z 1858 roku jest już A. Śmitkowski odnotowany jako komendarz w Mokronosie, z datą 1857 jako momentem instalacji w tej parafii.

${ }^{37}$ AAP, KA 1061.

${ }^{38}$ Tamże.

${ }^{39}$ Tamże.

${ }^{40}$ Elenchus universi cleri...1861, s. 19. Ks. A. Śmitkowski jako proboszcz parafii jutrosińskiej (w jego czasach świątynią parafialną był kościół pw. św. Krzyża) spisał dokument dotyczący objęcia (introdukcji) urzędu, w którym wykorzystał i zacytował - w formie glosy marginalnej - źródła dotyczące wcześniejszych dziejów parafii. Dokument ten (Opis kościoła i probostwa w Jutrosinie położonego w Archidyecezyi Poznańskiej, w Dekanacie Krobskim, do introdukcyi X. Antoniego Smitkowskiego) stanowi dzisiaj jedno z najważniejszych źródeł do dziejów kościołów jutrosińskich i często jest przywoływany w literaturze przedmiotu. R. Krzyżosiak, Kościót św. Elżbiety w Jutrosinie na tle historii parafii jutrosińskiej, Jutrosin 2008, s. 27, 164-168, 172. 
roku pełnoprawnym proboszczem (praepositus) ${ }^{41}$. Ponadto - od roku 1866 do 1870 - ks. A. Śmitkowski był dziekanem dekanatu krobskiego ${ }^{42}$. Jako proboszcz jutrosiński i dziekan krobski angażował się w nadzór (jako inspektor szkolny) nad elementarnym szkolnictwem katolickim na swoim terenie ${ }^{43}$.

Ksiądz Antoni Śmitkowski zmarł 31 maja 1871 roku w Jutrosinie w wieku 50 lat, w 24. roku kapłaństwa ${ }^{44}$. W „Dzienniku Poznańskim” ukazał się nekrolog zamieszczony przez jego ojca ${ }^{45}$.

Ks. A. Smitkowski wielokrotnie pojawia się na kartach Dziennika i korespondencji E. Bojanowskiego. Ich częste i intensywne w pewnym okresie kontakty dotyczyły ochronki w Rogożewie, której otwarcie jest głównym tematem prezentowanego tu listu. Jednak już wcześniej E. Bojanowski wspominał o nim w swoich pismach. W 1854 roku zanotował bowiem, że kwestarz tzw. Instytutu Gostyńskiego (ochronka, szpital) - w którego działalność E. Bojanowski wówczas bardzo mocno się angażował - wrócił z kwesty ze Świerczyny, gdzie od ks. A. Śmitkowskiego dostał hojny datek ${ }^{46}$. W tym samym roku przywołał też opinię o ks. A. Śmitkowskim jako rzutkim kapłanie, energicznie rozpowszechniającym, stanowiące w ówczesnych czasach jeszcze duszpasterską nowość, nabożeństwa majowe ${ }^{47}$. Jej autorką była wiejska dziewczyna, która przeprowadziwszy się z Grabonoga do Świerczyny, zauważyła u tamtejszego kapłana gorliwość W rozbudzaniu pobożności i życia religijnego wiernych, jakiej nie znała (lub w formach, których nie znała) ze swoich rodzinnych stron. Wizerunek ks. A. Śmitkowskiego jako kapłana bardzo zaangażowanego, aktywnego pod względem duszpasterskim, znajduje potwierdzenie w jego udziale w wydarzeniu o niebagatelnym znaczeniu dla obrazu życia religijnego Wielkopolski w XIX wieku. Chodzi mianowicie o misje prowadzone w latach 50. XIX wieku na terenie Wielkiego Księstwa Poznańskiego przez jezuitów, związane z próbą zainstalowania ich w pocysterskim klasztorze w Obrze. Te dobrze przygotowane i głoszone przez wybitnych kaznodziejów (m.in. o. Karola Antoniewicza) misje

${ }^{41}$ Elenchus universi cleri...1863, s. 19.

${ }^{42}$ Elenchus universi cleri...1866, s. 24; 1867, s. 25; 1869, s. 25; 1870, s. 25.

${ }^{43}$ L. Rzepecki, Obraz katolickich szkół elementarnych objętych Archidyjecezyjami Gnieźnieńska i Poznańska oraz Dyjecezyjami Chetmińska i Warmińska, Poznań 1867, s. 27-28.

${ }^{44}$ Elenchus mortuorum quorum animae piis Confratrum Suffragiis commendantur, w: Elenchus omnium ecclesiarum et universi cleri...1872, s. 55. Autor wspomnieniowego wydawnictwa w następujący sposób podsumował informację o śmierci ks. A. Śmitkowskiego: „Gorliwy pasterz umarł jako żołnierz na posterunku, sterawszy zdrowie w obowiązkowéj pracy” (T. Żychliński, Kronika żałobna rodzin wielkopolskich od 1863-1876 r. Z uwzględnieniem ważniejszych osobistości zmarbych w tym przeciagu czasu w innych dzielnicach Polski i na obczyźnie, Poznań 1877, s. 403).

45 „Dziennik Poznański”, 13 (1871), nr 124, s. 4: „Dziś w południe zmarł po długiém cierpieniu nagłą zaskoczony śmiercią najukochańszy syn mój ś. p. dziekan X. Antoni Śmitkowski, o czém donosi wszystkim znajomym i krewnym w smutku pogrążony ojciec. Eksportacya zwłok do kościoła odbędzie się w piątek przed wieczorem, pogrzeb zaś w sobotę dnia 3 czerwca $\mathrm{z}$ rana. Jutrosin, dnia 31 maja 1871".

${ }^{46}$ Bojanowski, Dziennik, t. 1, s. 328.

${ }^{47}$ Tamże, s. 367: „Powiada mi, że w całej parafii świerczyńskiej w każdej wsi odbywa się majowe nabożeństwo za powodem gorliwego plebana ks. Smitkowskiego”. 
parafialne, miały wywrzeć ogromny wpływ na pogłębienie życia religijnego w ówczesnej Wielkopolsce i podnieść je do „poziomu, jakiego Poznańskie przedtem nie znało" ${ }^{48}$. Pierwszym proboszczem, który zaprosił jezuitów na misje (warto zaznaczyć, że w państwie pruskim wierni nie znali tego pojęcia, a młodsze pokolenie nie zdawało sobie sprawy, że poza duchowieństwem diecezjalnym istnieje też kler zakonny ${ }^{49}$ ), był ks. Telesfor Masłowski z Krobii ${ }^{50}$. Po wielkim sukcesie krobskich misji podobne zaczęły odbywać się w innych wielkopolskich parafiach (łącznie w 48). Jedną z nich była Świerczyna, w której jezuickie misje ludowe miały miejsce w $1854 \mathrm{roku}^{51}$. W latach 1849-1857 administratorem tej parafii był ks. Antoni Śmitkowski, więc zorganizowanie tych głośnych i bardzo owocnych misji było wynikiem jego inicjatywy i efektem zapewne wielu zabiegów. Opisywany tu kapłan uchodził też w środowisku lokalnego duchowieństwa za dobrego kaznodzieję i sprawnego mówcę. Świadczy o tym opinia ks. Stanisława Gieburowskiego z Górki Duchownej ${ }^{52}$. W sytuacji, gdy nie mógł on pojechać na uroczystość otwarcia ochronki w Rokosowie, podczas której miał wygłosić wstępną przemowę, doradził E. Bojanowskiemu: „(..) do przemówki użyj ks. Szmitkow[skiego], który Ci się doskonale wywiąże" 53 .

${ }^{48}$ Wyrażeniem takim posłużył się Zygmunt Zieliński (Kościót katolicki w Wielkim Księstwie Poznańskim w latach 1848-1865, Lublin 1973, s. 259). Na podstawie bogatego materiału źródłowego zagadnienie to przedstawił Paweł Zając (Misje jezuitów w Wielkopolsce i ich obrzańska rezydencja w latach 1852-1855, „Ecclesia. Studia z Dziejów Wielkopolski”, 9 (2014), s. 187-209). Wiele na ten temat pisała też od 1852 roku prasa katolicka, głównie „Przegląd Poznański”.

${ }^{49} \mathrm{E}$. Bojanowski zanotował ciekawą obserwację, ilustrującą zjawisko nieświadomości istnienia kleru zakonnego wśród młodego pokolenia w Poznańskiem. Po kasacie zakonów w tym regionie widok człowieka w habicie wywoływał zdziwienie młodzieży i dociekania dotyczące pochodzenia tak oryginalnego w ich mniemaniu stroju: „Miałem dzisiaj zabawny, a przecież zarazem smutny dowód, jak dalece w teraźniejszem pokoleniu dziecięcem, nie został już ani ślad pamięci o klasztorach i zakonnikach, którzy w prowincji tutejszej zupełnie zniknęli i dopiero teraz pojawiać zaczynają się tu i ówdzie próbki odradzających się zakonów. Dziś bowiem jeden z naszych, na wakacjach bawiących w domu, chłopców, będąc na pogrzebie, zobaczył reformata, jednego z tych, co się w Prusach zachodnich utrzymali, a teraz w stronach tutejszych osadzić się pragną w jakim opuszczonym klasztorku i myślał, że to musi być jakiś pielgrzym, «bo był - powiada - w jakiejś szarej, podróżnej burce z kapturem ubrany»" - Bojanowski, Dziennik, t. 1, s. 139.

${ }^{50}$ Zając, Misje jezuitów, s. 193.

${ }^{51}$ Zając, Misje jezuitów, s. 189. Autor tego opracowania powołuje się na zestawienie sporządzone przez historyka zakonu z początków XX wieku (S. Załęski, Jezuici w Polsce, t. 5: Jezuici w Polsce porozbiorowej 1773-1905, cz 2: 1820-1905, Kraków 1906, s. 812). Zob. też Misje w latach 1852-1865 (mapa), w: Zieliński, Kościót katolicki, po s. 256.

${ }^{52}$ Ks. S. Gieburowski był przyjacielem i współpracownikiem E. Bojanowskiego. Poznali się, gdy od 1855 roku był on wikariuszem w parafii E. Bojanowskiego, tj. w Strzelcach Wielkich. Pod koniec życia, gdy z powodu stanu zdrowia założyciel służebniczek opuścił seminarium duchowne, ks. S. Gieburowski udzielił mu gościny na plebani w Górce Duchownej. E. Bojanowski spędził tam ostatni rok swego życia i tam zmarł. Zob. np. J. Glapiak, Błogosławiony Edmund Bojanowski w Górce Duchownej, Poznań 2005.

${ }^{53}$ List ks. Stanisława Gieburowskiego do E. Bojanowskiego z 27.02.1868, w: Korespondencja, t. 2 , s. 624 . 
W 1866 roku rozpoczęła się intensywna współpraca E. Bojanowskiego z ks. A. Śmitkowskim w związku z otwarciem ochronki w Rogożewie, miejscowości leżącej na terenie parafii Jutrosin. Przedrukowany tu list, który zachował się na plebani w Jutrosinie, był jednym z kilku, w których ustalano ostateczną datę założenia rogożewskiej ochronki ${ }^{54}$. Uroczystość jej otwarcia, na którą E. Bojanowski przybył mimo trudnych warunków atmosferycznych oraz dwudniowy pobyt (16-17 grudnia 1866 roku) w Jutrosinie w gościnie u ks. Śmitkowskiego, zostały zrelacjonowane w Dzienniku $u^{55}$. Z przywołanych przez E. Bojanowskiego opinii sióstr służebniczek pracujących w rogożewskiej ochronce wynika, że ks. A. Smitkowski był bardzo pozytywnie przez nie postrzegany ${ }^{56}$. $\mathrm{Z}$ drugiej strony zarówno ksiądz dziekan, jak i fundatorka ochronki (w sensie materialnym) - księżna Elżbieta Czartoryska byli z jej funkcjonowania bardzo zadowoleni $^{57}$. Założyciel służebniczek darzył ks. A. Śmitkowskiego dużym zaufaniem, powierzając jego rozstrzygnięciu różne finansowo-organizacyjne sprawy ochronki rogożewskiej ${ }^{58}$. Jutrosiński proboszcz podejmował też decyzje w pilnych sytuacjach, w których siostry nie miały czasu zapytać o zgodę założyciela lub przełożonej j9. Krótko po otwarciu ochronki w Rogożewie zainteresowali się nią lokalni pruscy urzędnicy, wysuwając nieuzasadnione zarzuty ${ }^{60}$. E. Bojanowski liczył wówczas na to, że ks. A. Śmitkowski załatwi tę sprawę, interweniując u władz: „Dziekan wmiesza się w to, aby próżnych nie czyniono trudności”" W ochronce rogożewskiej pojawiły się między pracującymi tam trzema siostrami jakieś konflikty. Nie była to w powstającym zgromadzeniu nowa sytuacja. Wcześniej były one rozwiązywane po rozeznaniu sprawy przez założyciela lub przełożoną. Siostra Anna Gross uważała, że nie może dojść do porozumienia z pozostałymi dwoma siostrami i nalegała, aby ją przenieśćc ${ }^{2}$. Założyciel miał nadzieję, ,że stosunek między nimi naprawi się, trzeba tylko wyrozumiałości”, jednocześnie dodając jednak, iż „o zmianie [przeniesieniach sióstr - Ł.P.], jeśli

${ }^{54}$ Bojanowski, Dziennik, t. 3, s. 772.

${ }^{55}$ Tamże, s. 775. Warto podkreślić, że ta grudniowa eskapada była zapewne wyzwaniem dla chorowitego i coraz bardziej cierpiącego założyciela służebniczek. Ponad 30-kilometrową trasę pokonywano konnym zaprzęgiem saniami, przy obficie padającym śniegu oraz silnym wietrze.

${ }^{56}$ „Z Ochronki w Rogożewie [list - Ł.P.] (...) Siostry (...) Ks. Dziekana nie mogą się nachwalić” (Bojanowski, Dziennik, t. 4, s. 10).

${ }^{57}$ Przełożona służebniczek - siostra Elżbieta Szkudłapska - donosiła założycielowi: „W Rogożewie (...) Ks. Dziekan i Księżna zadowoleni” (Bojanowski, Dziennik, t. 4, s. 110).

${ }^{58}$ Tamże, s. 83, 127, 132, 144.

${ }^{59}$ Chodziło wówczas o pozwolenie jednej ze służebniczek na opuszczenie ochronki w celu odwiedzenia śmiertelnie chorej siostry. Odwiedziny te odbyły się, jak wymagała tego krystalizująca się reguła zgromadzenia, w towarzystwie innej służebniczki - Tamże, s. 103.

${ }^{60}$ Tamże, s. 103-104: „Komisarz obwodowy był w Ochronce. Zarzucał, że bez pozwolenia regencji przybyły siostry, że dzieci uczą, że składki na nie są zbierane (??)”.

${ }^{61}$ Tamże, s. 104, 107.

${ }^{62}$ Tamże, s. 216. 
będzie potrzeba pomyślemy"63. Tymczasem poprosił on ks. A. Śmitkowskiego, aby jako duchowny opiekun ochronki rozeznał kwestię konfliktów między siostrami. Ksiądz dziekan z góry wyraził swój pogląd na temat częstego przenoszenia sióstr:

Te ciągłe translokacje, to prawdziwa klęska dla zgromadzenia. Na życzenia sióstr, jak mi się zdaje, nie powinny nigdy takie translokacje następować. Karność w tej mierze powinna być surowa. Wedle Rodrycjusza trzeba siostrom ślepego posłuszeństwa ${ }^{64}$.

Mimo tej kategorycznej opinii, po rozpoznaniu i rozważeniu tej konkretnej sytuacji, ks. A. Śmitkowski doszedł jednak do wniosku, że „,siostrę Annę trzeba zmienić” ${ }^{65}$. W lipcu i sierpniu 1868 roku siostry z Rogożewa informowały założyciela, że ks. dziekan A. Śmitkowski jest bardzo poważnie chory. W końcu sierpnia miał udać się na operację do Berlina. Ostatecznie zrezygnował z tych planów w związku ze stopniową poprawą samopoczucia. Jutrosińscy parafianie w intencji swojego proboszcza odprawiali nowennę do Matki Bożej Pocieszenia ${ }^{66}$.

W 1867 roku E. Bojanowski planował wydawanie pisma dla ludu. Byłaby to jego kolejna inicjatywa wydawnicza (do jej uskutecznienia ostatecznie jednak nie doszło) adresowana do włościan, wcześniej bowiem (1860, 1862 rok) wydawał „Rok Wiejski" 67 . Pismo to, jak wszystkie tego typu periodyki, miało zawierać wiele treści religijnych, dlatego wydawca próbował pozyskać jako autorów księży. Z propozycją napisania artykułów zwrócił się więc m.in. do ks. A. Śmitkowskiego. Ten początkowo wyraził chęć napisania ,artykuliku”, później jednak były problemy z wyegzekwowaniem od niego obiecanego tekstu. Nie był on zresztą wyjątkiem. Ks. Antoni Klajner z Dubina pisał na ten temat do E. Bojanowskiego: „Z pracą literacką u mnie i u sąsiada mego w Jutrosinie [ks. A. Śmitkowskiego Ł.P.] nie sporo idzie, tak jakoś nie ma czasu, a może opieszałość [...]"68. Ks. A. Smitkowski tłumaczył się podobnie, prosząc o cierpliwość i dodając, że nie ma ambicji autorskich i brak mu w tej mierze doświadczenia oraz biegłości: „Co do nadesłania żądanego artykuliku do pisma ludowego to wyznaję, żem w rzemiośle pisarskim wcale nie biegły. Przeczuwam, że choćbym co sklecił, to się na nic nie przyda. Stąd też do autorskiego zawodu się nie porywam. Nie odmawiam, bym przy czasie swobodnym coś na próbę nie miał przesłać, lecz proszę tylko o cierpliwość" ${ }^{69}$. Warto nadmienić, że nie wszyscy duchowni wymawiali się od

${ }^{63}$ Tamże, s. 217.

${ }^{64}$ List ks. A. Śmitkowskiego do E. Bojanowskiego z 17.12.[18]67, w: Korespondencja, t. 2, s. 613. Por. relację na temat tego listu w Dzienniku (t. 4, s. 218-219).

${ }^{65}$ Tamże, s. 232.

${ }^{66}$ Tamże, s. 316, 333, 347-349, 354, 377, 379.

${ }^{67}$ Zob. np. G. Gzella, „Rok Wiejski” - E. Bojanowskiego pismo dla ludu, „Przegląd Powszechny", (1992) nr 2, s. 232-245.

${ }^{68}$ List ks. Antoniego Klajnera do E. Bojanowskiego z 4.11.[18]67, w: Korespondencja, t. 2, s. 605 .

${ }^{69}$ List ks. A. Śmitkowskiego do E. Bojanowskiego z 17.12.[18]67, w: Korespondencja, t. 2, s. 614 . 
autorskiego udziału w wydawniczym projekcie. Bardzo szybko na propozycję E. Bojanowskiego odpowiedział, znany szerzej $z$ pisarskiej i wydawniczej działalności i współpracujący już z nim onegdaj przy „Roku Wiejskim”, ks. Symforian Tomicki ${ }^{70}$.

Kontakty E. Bojanowskiego z ks. A. Śmitkowskim zakończyły się wraz z zamknięciem ochronki w Rogożewie w 1869 roku. Z relacji zanotowanych przez założyciela służebniczek wynika, że układały się one bardzo dobrze, a ksiądz angażował się w sprawy ochronki i cieszył się dużym zaufaniem ze strony E. Bojanowskiego.

\section{Osoby wymienione w liście}

\section{Rozalia Krzekotowska}

Sprawa skierowania do nowicjatu służebniczek w Jaszkowie kandydatki Rozalii Krzekotowskiej z parafii Jutrosin jest jednym z wątków prezentowanego tu listu. Założyciel służebniczek informuje w nim ks. A. Śmitkowskiego, że przybyła do niego rzeczona kandydatka i przekazała mu list od księdza datowany 22 listopada 1866 roku. Kwestia przysłania do Jaszkowa nowej kandydatki była uzgadniana z E. Bojanowskim już wcześniej. Pisała do niego w tej sprawie księżna Elżbieta Czartoryska, która od dłuższego też czasu konsultowała z założycielem warunki i termin otwarcia ochronki w swoich dobrach. Streszczając jej niezachowany list, E. Bojanowski zapisał w Dzienniku, że do otwarcia ochronki w Rogożewie wszystko zostało już przygotowane, jest też w tamtych stronach kilka kandydatek, $\mathrm{a}$,jedną z funduszem przyśle [księżna - Ł.P.] w tych dniach do Jaszkowa" ${ }^{1}$. Kilka dni później - 25 listopada 1866 roku - anonsowana kandydatka, jadąc do Jaszkowa, wstąpiła do Grabonoga i przekazała założycielowi dwa listy polecające: od księżnej oraz od ks. A. Śmitkowskiego ${ }^{72}$. Ten drugi zachował się. Jest on opinią, świadectwem moralności, wystawionym kandydatce przez duszpasterza. Ks. A. Śmitkowski napisał:

Oddawczyni tego pisma, Rozalia Krzekotowska prosi mnie, abym jej świadectwo zachowania się wystawił. Czynię to chętnie, bo Rozalia Krzekotowska zawsze moralne i wzorowe życie prowadziła, na nabożeństwo z wielką gorliwością uczęszczała, do sakramentów św. często przystępowała, a przy tem usilną pracowitością przyświecała. Tuszę, że dla instytutu służebniczek pożyteczną będzie ${ }^{73}$.

${ }^{70}$ Ks. Tomicki niebawem po zaproszeniu go do współpracy przysłał E. Bojanowskiemu dwa teksty. J. Biesiada, Ksiądz Symforian Tomicki - pisarz, redaktor ,,Szkółki Niedzielnej” i „, Oświaty”, „Ecclesia. Studia z Dziejów Wielkopolski”, 9 (2014) s. 178. Por. Bojanowski, Dziennik, t. 4, s. 201, 205, 213, 214.

${ }^{71}$ Bojanowski, Dziennik, t. 3, s. 767. Informacja, że kandydatka dysponowała funduszem na utrzymanie w nowicjacie, zdaje się świadczyć o tym, że pochodziła ona z zamożniejszej warstwy ludności wiejskiej.

72 Tamże, s. 769.

${ }^{73}$ List ks. A. Śmitkowskiego do E. Bojanowskiego z 22.11.[18]66, w: Korespondencja, t. 2, s. 531. 
Autor Dziennika również skreślił kilka słów polecających kandydatkę siostrze kierującej jaszkowskim nowicjatem ${ }^{74}$. Prawdopodobnie następnego dnia Rozalia Krzekotowska przybyła do Jaszkowa i wstąpiła do nowicjatu. Jednak kilka dni później (6 grudnia) E. Bojanowski dostał informację, że „kandydatka Rozalia Krzekotowska wróciła do domu"75. Zatem jej pobyt w nowicjacie był niezwykle krótki, zaledwie dwutygodniowy. Jednak 4 marca 1867 roku R. Krzekotowska pojawiła się u założyciela i ponownie wyraziła chęć wstąpienia do nowicjatu. Zapisał on na ten temat następującą relację:

Była tu dziś u mnie, idąc na 40-godzinne nabożeństwo do klasztoru [bazylika filipinów w Gostyniu - Ł.P.], Rozalia Krzekotowska z Pawłowa. Wprasza się znów do Nowicjatu. Radzę jej, aby ks. Dziekan [A. Śmitkowski - Ł.P.] zechciał napisać za nią do s. Przełożonej. Dałem jej książeczkę o Annie Marii Taigi i trzy obrazki dla niej i dwóch towarzyszek podróży ${ }^{76}$.

Można się domyślać, że po powrocie do domu i głębszej refleksji R. Krzekotowska uznała, iż pochopnie, pod wpływem pierwszego wrażenia trudności zakonnego życia, podjęła decyzję o opuszczeniu nowicjatu. Należy zwrócić uwagę na to, że E. Bojanowski do sprawy jej ewentualnego powrotu nie podchodził jednak zbyt entuzjastycznie. Wyraźnie uchylił się on od podjęcia decyzji w jej sprawie, zostawiając to siostrze przełożonej w Jaszkowie i polecając kandydatce zwrócenie się o powtórną opinię i rekomendację do duszpasterza. Podejście to wynikało z wcześniejszych doświadczeń założyciela służebniczek. Zdarzało się bowiem, że dziewczęta, które odeszły ze służby ochronkowej, ponownie chciały po jakimś czasie do niej wstępować. E. Bojanowski nie był raczej skłonny na to pozwalać, namawiając zawsze kandydatki mające wątpliwości i wyrażające chęć odejścia ze zgromadzenia do niespieszenia się z pochopną decyzją i podjęcia dłuższego namysłu i rozeznania ${ }^{77}$. Ponadto siostry z ochronki w Rogożewie, już w styczniu

${ }^{74}$ Bojanowski, Dziennik, t. 3, s. 769.

${ }^{75}$ Tamże, s. 772.

${ }^{76}$ Tamże, t. 4, s. 44. W zapisie tym pojawia się też informacja, że kandydatka pochodziła z Pawłowa, wsi położonej nieopodal Jutrosina.

77 Jednym z przykładów niestałości powołania była Magdalena Stachowiak. 1 kwietnia 1855 roku wstąpiła ona do zgromadzenia i została ochroniarką w Podrzeczu, a później przewodniczką tej ochronki. Założyciel miał bardzo dobre zdanie o jej pobożności i powołaniu, do tego stopnia, że zamierzał uczynić ją przełożoną wszystkich (trzech wówczas istniejących) ochronek. Jednak w październiku 1855 roku wyraziła ona stanowcze żądanie uwolnienia jej ze służby ochronkowej przed upływem rocznego okresu posługi, do jakiego się zobowiązała, wstępując do rodzącego się zgromadzenia. Odejście to odbyło się w nieprzyjemnej atmosferze, gdyż Magdalena, będąc w zgromadzeniu, prowadziła zakulisowe rozmowy w sprawie przyjęcia jej na służbę do ks. Franciszka Hübnera w Książu Wielkopolskim, a następnie opuściła ochronkę bez pożegnania. Po jakimś czasie E. Bojanowskiego poinformowano, że Magdalena żałuje swojej decyzji, co założyciel skomentował w następujący sposób: „Magdalena już płacze i rozpacza, że opuściła Ochronkę. Pragnęłaby wrócić, ale sama czuje, że już nierychło. Niech dziękuje tym, którzy ją do tego skłonili”. Bojanowski, Dziennik, t. 1, s. 767. 
1867 roku, donosiły założycielowi, że R. Krzekotowska myśli o powrocie do nowicjatu. W streszczeniu tegoż listu E. Bojanowski zanotował, że opinia rogożewskich służebniczek na temat ewentualnego powrotu tej kandydatki była negatywna: „Rozalii Krzekotowskiej nie radzą siostry przyjmować”78.

\section{Księżna Elżbieta z Działyńskich Czartoryska}

Wspomniana $\mathrm{w}$ przedrukowanym tu liście księżna Elżbieta pochodziła ze znanego wielkopolskiego rodu arystokratycznego Działyńskich. Jej ojciec Tytus - został zapamiętany przede wszystkim jako mecenas kultury - twórca biblioteki i muzeum w Kórniku, wydawca źródeł historycznych ${ }^{79}$. Elżbieta urodziła się w 1826 roku. Wychowana została w Galicji. Była starannie i wszechstronnie wykształcona. W 1848 roku, na polecenie rodziców, wyszła za starszego od niej o 22 lata księcia Adama Konstantego Czartoryskiego, wdowca, którego pierwszą żoną była Wanda, córka księcia Antoniego Radziwiłła, namiestnika Wielkiego Księstwa Poznańskiego i Luizy Hohenzollern. W wyniku obu swoich małżeństw książę Czartoryski związał się z Wielkopolską. Po ślubie z Elżbietą Działyńską Adam Konstanty Czartoryski nabył dobra w Poznańskiem, dając tym samym początek wielkopolskiej linii Czartoryskich, której kontynuatorami byli jego synowie z drugiego małżeństwa - Zygmunt i Zdzisław. Adam Konstanty i Elżbieta mieli pięcioro dzieci, z których dwoje zmarło w dzieciństwie. Księżna Elżbieta uchodziła za gorącą patriotkę oraz osobę bardzo pobożną. Kontakty i współpraca z księdzem Janem Koźmianem zdają się wskazywać, że sympatyzowała ze środowiskami konserwatywno-zachowawczymi i ultramontańskimi. Przyjacielem domu i częstym gościem u Czartoryskich był ks. Edward Likowski - późniejszy biskup i arcybiskup poznański. Na pogrzebach Adama Konstantego i Elżbiety wygłosił on utrzymane w bardzo pochwalnym tonie mowy żałobne. We wspomnieniach ks. E. Likowskiego, Józefa Łosia i Marcelego Mottego zwracano uwagę na bierność polityczną księcia Adama Konstantego oraz pewne wyobcowanie, zamknięcie w kręgu najbliższej rodziny, które miało cechować tego twórcę wielkopolskiej linii rodu Czartoryskich ${ }^{80}$. Wynikało to jednak raczej ze specyfiki jego charakteru, a nie z braku patriotyzmu i uczuć narodowych ${ }^{81}$. W relacjach o księżnej Elżbiecie podkreślano, że była ona powszechnie znana $\mathrm{z}$ angażowania się $\mathrm{w}$ działalność dobroczynną, hojnie obdarowywała też świątynie ${ }^{82}$. Dbała także bardzo o to, aby

${ }^{78}$ Bojanowski, Dziennik, t. 4, s. 11.

${ }^{79}$ Zob. np. B. i M. Kosmanowie, Tytus Dziatyński i jego dzieło. 150 lat Biblioteki Kórnickiej, Wrocław 1978; S.K. Potocki, B. Wysocka, Tytus Działyński 1796-1861, Poznań 2002.

${ }^{80}$ X.E. Likowski, Mowa żałobna na cześć śp. Xięcia Adama Konstantego Czartoryskiego zmartego w Rokosowie dnia 19 grudnia 1880 r. powiedziana w kościele parafialnym krobskim na nabożeństwie żałobnem dnia 23 grudnia, Poznań (b.d.); M. Motty, Przechadzki po mieście (Poznaniu), oprac. i wstępem opatrzył Z. Grot, przypisy przeredagował i uzupełnił W. Molik, t. 2, Poznań 1999, s. 171-172; A. Kwilecki, W oczach przybysza. Józef Łoś w Poznańskiem, w: A. Kwilecki, Ziemiaństwo wielkopolskie, Warszawa 1998, s. 235-240.

${ }^{81}$ Por. T. Żychliński, Złota księga szlachty polskiéj, t. 8, Poznań 1886, s. 116.

${ }^{82}$ S. Karwowski, Historja Wielkiego Księstwa Poznańskiego, t. 3: 1890-1914, Poznań 1931, s. 73-74. 
edukacja i wychowanie jej dzieci miały charakter polski i patriotyczny. Równie pilnie troszczyła się o dzieci męża z pierwszego małżeństwa, które dzieciństwo spędziły w Berlinie i były wcześniej wychowywane pod wpływem kultury niemieckiej. Elżbieta Czartoryska zmarła w Rokosowie w 1896 roku. Pochowana została obok zmarłego 16 lat wcześniej męża w podziemiach kościoła w Krobi k. Gostynia ${ }^{83}$. Zdzisław Czartoryski - syn Elżbiety i Adama Konstantego - był głównym fundatorem nowego kościoła parafialnego w Jutrosinie. Wzniesiona na początku XX wieku neoromańska świątynia otrzymała wezwanie św. Elżbiety. Wybór patronki kościoła nie był zapewne przypadkowy i miał przypominać o matce kolatora świątyni ${ }^{84}$.

W kontekście współpracy E. Bojanowskiego z księżną Czartoryską szerszego komentarza wymaga kwestia miejsca zamieszkania księżnej i jej rodziny. Sprawa ta jest dość oczywista, jednak w przypadku nazwy miejscowości, która zapisana została w korespondencji i Dzienniku E. Bojanowskiego, pojawiają się poważne wątpliwości. Ich źródłem nie jest jednak autor, ale wydawca i komentator. L. Smołka dokonał bowiem błędnej identyfikacji miejscowości, którą E. Bojanowski podawał jako miejsce zamieszkania księżnej. W Korespondencji Edmunda Bojanowskiego edytor zachował oryginalny zapis Sielec, w przypisie precyzując jego położenie w następujący sposób: „W domu Elżbiety (zimą w Poznaniu, latem w pobliskim Sielcu) [...] ${ }^{185}$. Natomiast w wydaniu Dziennika L. Smołka każdorazowo uzupełnia zapis tej miejscowości w formie Sie[d]lec, a w przypisie powtarza skorygowaną informację z wcześniejszego wydawnictwa: „W domu Elżbiety (zimą w Poznaniu, latem w pobliskim Siedlcu k. Kostrzyna)

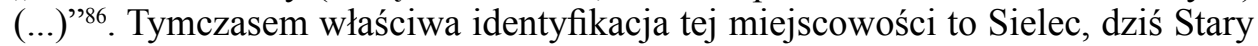
Sielec, koło Jutrosina na południu Wielkopolski ${ }^{87}$. Przekonuje o tym analiza literatury przedmiotu. Stanisław Karwowski w swojej Historii Wielkiego Księstwa Poznańskiego w pośmiertnym wspomnieniu o E. Czartoryskiej wyraźnie stwierdza bowiem: „Po kilkoletnim pobycie w Dreźnie powrócili księstwo do Wielkopolski

${ }^{83}$ Najbardziej gruntownym opracowaniem na temat wielkopolskiej linii Czartoryskich jest tekst Andrzeja Kwileckiego (Czartoryscy herbu Pogoń litewska, w: Ziemiaństwo wielkopolskie. W kręgu arystokracji, red. A. Kwilecki, Poznań 2004, s. 326-380) oraz biografia jednego z późniejszych przedstawicieli rodu autorstwa Jakuba Morysona (Ksiązę Olgierd Czartoryski (1888-1977). Życie i działalność społeczno-polityczna, Kraków 2012). Zob. też M. Kukiel, Czartoryski Adam Konstanty, w: Polski stownik biograficzny, t. 4, Kraków 1938, s. 269-270 oraz wiele wzmianek w opracowaniach A. Kwileckiego (Ziemiaństwo wielkopolskie, Warszawa 1998; Wielkopolskie rody ziemiańskie, Poznań 2010).

${ }^{84}$ R. Krzyżosiak, Z dziejów parafii rzymskokatolickiej w Jutrosinie. 100 lat istnienia obecnego kościoła parafialnego, Jutrosin 2002, s. 18.

${ }^{85}$ Korespondencja, t. 1, s. 350, przyp. 702.

${ }^{86}$ Bojanowski, Dziennik, t. 2, s. 75, przyp. 268.

${ }^{87}$ Warto odnotować, że późniejszy przedstawiciel rodu Czartoryskich - książę Olgierd (wnuk Elżbiety i Adama Konstantego) ożeniwszy się z arcyksiężną Mechtyldą Habsburg, rozpoczął w 1915 roku budowę nowego pałacu w Starym Sielcu, który odpowiadałaby randze siedziby rodu spowinowaconego z austriacką rodziną cesarską. Jednak wskutek kryzysu finansowego spowodowanego pierwszą wojną światową budowy nigdy nie ukończono. Do dziś pałac ten stoi w stanie surowym. Moryson, Książe Olgierd Czartoryski, s. 85. 
i osiedli w ustronnym dworze w Sielcu pod Jutrosinem" ${ }^{88}$. L. Smołka odnotował w cytowanych wyżej przypisach opracowanie S. Karwowskiego, ale z jakichś względów nie przyjął do wiadomości podanej tam informacji. Kategorycznie na temat miejsca zamieszkania Czartoryskich wypowiedział się też, nieprzywoływany przez L. Smołkę, znawca tematyki ziemiaństwa wielkopolskiego - Andrzej Kwilecki:

Czartoryscy przez dłuższy czas szukali odpowiednich majętności i dworów.

Nabyli w Poznańskiem Sarbinowo, Przyborowo, Jutrosin ze Starym Sielcem, Dubin z Wielkim Borem. W latach 1865-1867 mieszkali w Starym Sielcu ${ }^{89}$.

Pomijając to, już sama logiczna analiza tekstów E. Bojanowskiego świadczy o tym, że ów Sielec, w którym mieszkali Czartoryscy, nie mógł być położony w okolicach Poznania, koło Kostrzyna. Jaki bowiem sens miałoby zakładanie przez księżną ochronki w Rogożewie k. Jutrosina, skoro mieszkała ona w okolicach Poznania? Tereny te dzieli odległość ponad $100 \mathrm{~km}$, tymczasem księżna bardzo często odwiedzała ochronkę i vice versa - siostry z dziećmi odwiedzały księżną. Przy takiej lokalizacji odwiedziny podopiecznych ochronki byłyby niemożliwe. Wiele fragmentów Dziennika E. Bojanowskiego świadczy o tym, że Sielec położony był bardzo blisko Jutrosina. Dla przykładu relacja na temat wizytacji ochronki w Rogożewie z 27 czerwca 1867 roku:

Byłem na obiedzie u ks. Smitkowskiego w Jutrosinie. Po południu byłem z nim i z o. refor[matem] Rafałem Credo w Rogożewie (...) Z Rogożewa pojechaliśmy do Księżnej do Sie[d]lca. Byliśmy na nieszporach [w Jutrosinie - Ł.P.], potem znów w Sie[d]lcu na kolacji. Wróciliśmy na noc do Jutrosina ${ }^{90}$.

Takie częste przemieszczanie się $\mathrm{w}$ ciągu jednego dnia między wymienionymi miejscowościami byłoby możliwe tylko przy założeniu, że położone są one bardzo blisko siebie, w odległości zaledwie kilku kilometrów. Żadną miarą nie może być mowy, aby chodziło w tym przypadku, jak sugeruje L. Smołka, o Siedlec k. Kostrzyna. Nawet przy dzisiejszych możliwościach komunikacyjnych pokonywanie takich odległości w ciągu jednego popołudnia byłoby wyzwaniem, a uwzględniając realia XIX-wieczne, w grę musiałaby wchodzić jakaś teleportacja ${ }^{91}$.

Kontakty i współpraca E. Bojanowskiego z Elżbietą Czartoryską ogniskowały się - podobnie jak w przypadku ks. A. Śmitkowskiego - wokół ochronki w Rogożewie, później w Rokosowie. Księżna na długo przed nawiązaniem współpracy $\mathrm{z}$ E. Bojanowskim słyszała o jego dobroczynnych dziełach

${ }^{88}$ Karwowski, Historja Wielkiego Księstwa, s. 73.

${ }^{89}$ Kwilecki, Czartoryscy herbu Pogoń, s. 329.

${ }^{90}$ Bojanowski, Dziennik, t. 4, s. 115.

${ }^{91}$ Identyfikacja miejscowości, szczególnie wsi, występujących na kartach Dziennika i korespondencji Bojanowskiego, nastręcza niekiedy problemów. W opisywanym tu przypadku wydawca Dziennika pod jedną występującą w indeksie nazwą Siedlec umieścił co najmniej trzy różne miejscowości - Stary Sielec koło Jutrosina, Siedlec między Gostyniem i Pępowem oraz Siedlec koło Kostrzyna. Gwoli ścisłości warto dodać, że istnieje jeden zapis w Dzienniku (t. 4, s. 204) sugerujący, jakoby księżna Czartoryska miała przebywać w Siedlcu k. Kostrzyna, jednak wszystkie pozostałe zapisy odnoszą się do Starego Sielca k. Jutrosina. 
i wspomagała je datkami ${ }^{92}$. W Dzienniku znajdują się też wzmianki o towarzyskich kontaktach E. Bojanowskiego z rodziną Czartoryskich, które najczęściej związane były z ich wizytami w bazylice na Świętej Górze k. Gostynia ${ }^{93}$. Pierwsze informacje o tym, że Czartoryscy zainteresowani są założeniem w swoich dobrach ochronki służebniczek pojawiają się we wrześniu 1866 roku$^{94}$. E. Bojanowski, w związku z brakami kadrowymi, skłonny był odłożyć powstanie ochronki w Rogożewie do przyszłego roku ${ }^{95}$. Jednak Czartoryscy bardzo nalegali na jak najszybsze jej otwarcie. Księżna zwracała się w tej sprawie do ks. Jana Koźmiana - duchownego komisarza służebniczek. Ten z kolei, obiecawszy jej swoje wsparcie, naciskał na E. Bojanowskiego i siostrę przełożoną Elżbietę Szkudłapską, aby założenie ochronki w dobrach Czartoryskich uskutecznić możliwie szybko ${ }^{96}$. E. Bojanowski ustalił datę otwarcia ochronki w Rogożewie na 16 grudnia 1866 roku. Stało się to miesiąc później niż spodziewali się Czartoryscy, ale w porównaniu z innymi ochronkami należy stwierdzić, że tempo jej powstania, począwszy od pomysłu $\mathrm{z}$ września do jego realizacji w grudniu, było ekspresowe.

Z zapisów Dziennika wynika, że współpraca założyciela służebniczek z fundatorką ochronki układała się dobrze. Księżna angażowała się w sprawy ochronki, odwiedzała siostry i dzieci, te z kolei przy okazji świąt i imienin składały księżnej powinszowania, prosząc E. Bojanowskiego o przysłanie wierszyków na tę okazję ${ }^{97}$. Specyficznym aspektem funkcjonowania ochronki w Rogożewie było prowadzenie przez tutejsze siostry lazaretu, w którym opiekowano się opuszczonymi, obłożnie chorymi mieszkańcami okolicznych miejscowości. Księżna Czartoryska w ramach pomocy dla ochronki przysłała siostrom w marcu 1867 roku apteczkę homeopatyczną i zalecała używanie zawartych w niej specyfików w leczeniu podopiecznych lazaretu ${ }^{98}$. Z lekami homeopatycznymi zetknął się E. Bojanowski już wcześniej. Okazuje się, że w ówczesnych czasach, jako pewna nowość i moda, były one popularne wśród przedstawicieli bogatszego ziemiaństwa $^{99}$. E. Bojanowski przejawiał daleko idący sceptycyzm, co do

${ }^{92}$ Rzecz dotyczyła materialnego wsparcia księżnej dla Instytutu Gostyńskiego w roku 1856 (Bojanowski, Dziennik, t. 2, s. 75).

${ }^{93}$ Bojanowski, Dziennik, t. 3, s. 717, 741, 750; t. 4, s. 175, 296, 398.

${ }^{94}$ List E. Czartoryskiej do E. Bojanowskiego z 20.09.[18]66, w: Korespondencja, t. 2, s. 508. Por. Bojanowski Dziennik, t. 3, s. 740.

${ }^{95}$ Listy E. Bojanowskiego do E. Czartoryskiej z 14.10.1866 i 16.11.1866, w: Korespondencja, t. 1, s. 350,360 .

${ }^{96} \mathrm{~W}$ liście z 17 października 1866 roku J. Koźmian kategorycznie stwierdzał: „Księżnie trzeba koniecznie dać siostry”. 10 listopada znowu ponaglał E. Bojanowskiego: „Księżna pisze do mnie: «jesteśmy na siostry gotowi (...)». Teraz zrób Pan, co można. Niepodobna zwłóczyć”. 16 listopada utyskiwał z kolei, że „Księżna koniecznie się chciała na miejscu sióstr doczekać i miała w tym ważne powody. Tak się nie doczeka". O naciskach J. Koźmiana wspominała też E. Bojanowskiemu siostra E. Szkudłapska - Korespondencja, t. 2, s. 512, 514, 529.

${ }^{97}$ Bojanowski, Dziennik, t. 4, s. 10, 68, 83, 108, 235, 316.

${ }^{98}$ Tamże, s. 56.

99 Bojanowski, Dziennik, t. 1, s. 321: „Była tu [w Instytucie Gostyńskim - Ł.P.] dziś [15.03.1854 - Ł.P.] pani Łubieńska Julianowa z Pudliszek. Zwiedzała cały zakład i opowiadając nam nader pomyślne skutki kuracji homeopatycznych, wydobyła z kieszeni pudełko z maleńkiemi 
używania tych specyfików w placówkach służebniczek. Wynikał on z założenia, że za leczenie chorych odpowiadają lekarze, natomiast "siostry są tylko do pielęgnowania chorych, a nie do leczenia na swoją rękę"100. Mimo krytycznej opinii założyciela na temat samowolnego stosowania homeopatycznych leków przez służebniczki wiadomo, że apteczka podarowana przez księżnę Czartoryską była w rogożewskim lazarecie wykorzystywana ${ }^{101}$.

Funkcjonowanie ochronek często nastręczało założycielowi i zgromadzeniu wielu problemów. Na tle finansowych powinności fundatorów, odrobku, jaki w większości ochronek siostry wykonywały w dobrach ziemiańskich, itp., spraw często dochodziło do nieporozumień, sporów, wzajemnych żalów. Czasem skutkowały onezamykaniemochronek. Nawetw przypadkutakzamożnej fundatorki jak księżna Czartoryska pojawiły się pewne trudności z wyegzekwowaniem zobowiązań - konkretnie rocznej zwyczajowej ofiary na nowicjat w Jaszkowie. Sprawa ta jest interesująca ze względu na fakt, że E. Bojanowski czuł pewne skrępowanie wobec konieczności stanowczego przypomnienia księżnej o jej obowiązku i próbował uczynić to za pośrednictwem osób trzecich. Postanowił zwrócić się do ks. A. Śmitkowskiego, ,aby księżnie wspomniał o zwykłej ofierze na Nowicjat" 102 . Całą tą sytuacją - zwlekaniem i skrupułami E. Bojanowskiego w kwestii wyegzekwowania od księżnej opłaty - zniecierpliwiona była przełożona E. Szkudłapska. Wykazała się ona - jako odpowiedzialna za finanse zgromadzenia - pragmatycznym podejściem do problemu. Zaproponowała mianowicie, aby ks. J. Koźmianowi zlecić przypomnienie księżnej o opłacie na nowicjat ${ }^{103}$. Niewyartykułowany expressis verbis, ale domyślny przekaz siostry E. Szkudłapskiej był następujący - skoro J. Koźmian wcześniej, na prośby księżnej, tak bardzo zabiegał i naciskał na przełożoną i założyciela w sprawie jak najszybszego otwarcia ochronki w Rogożewie, to teraz mógłby napisać do księżnej list ponaglający do uiszczenia opłaty nowicjatowej. W końcu siostra E. Szkudłapska, wizytując ochronkę w Rogożewie, osobiście udała się do księżnej i przypomniała jej o obowiązku, na co otrzymała odpowiedź, że księżna „co do ofiary zobaczy, bo teraz nie ma" 104 . Po upływie dwóch miesięcy ks. J. Koźmian stanowczo domagał się od E. Bojanowskiego, aby ten koniecznie napisał do księżnej w sprawie ofiary. W końcu napisał on ów list, jednocześnie prosząc ks. J. Koźmiana o „poparcie naszego interesu u Księżnej” ${ }^{105}$. W liście do E. Czartoryskiej E. Bojanowski wyjaśniał jej, że taki coroczny datek jest

flaszeczkami zawierającymi rozliczne pigułeczki wielkości lukrowanego maku, z których niektóre dała zażyć kilku chorym na rany twierdząc, że tym sposobem, za pomocą środków wewnętrznych, nierównie łatwiej i trwalej wyleczą się rany, niżeli wszelkimi zewnętrznymi środkami”.

${ }^{100}$ Bojanowski, Dziennik, t. 4, s. 56, podobna opinia s. 67.

${ }^{101}$ Tamże, s. 144.

${ }^{102}$ Tamże, s. 89. Siostra E. Szkudłapska musiała przypominać założycielowi o braku tej ofiary, skoro kilka dni później znowu pisał, że „do księżnej lepiej udamy się przez ks. Smitkowskiego” (Tamże, s. 95).

${ }^{103}$ Tamże, s. 94.

104 Tamże, s. 110.

${ }^{105}$ Tamże, s. 166. 
zwyczajowo przyjęty jako forma wynagrodzenia dla nowicjatu za przygotowanie sióstr, wspominał o potrzebach nowicjatu, który musi spłacić koszty budowy nowej siedziby itp. Wyraźnie zauważalne są w tym tekście symptomy wspomnianego wyżej skrępowania autora, który zaczyna słowami: „Z nieśmiałością zanoszę do J[aśnie] O[świeconej] Pani następującą prośbę”, kończy natomiast: „Przepraszając najmocniej za ośmielenie się nasze, zostają pełen głębokiego uszanowania (...)"106. Księżna musiała zapytać, ile wynosi opłata nowicjatowa, skoro w kolejnym liście E. Bojanowski odpowiedział, iż większość fundatorów ochronek wpłacało 150 talarów, jednocześnie pisząc znowu, że tylko pilna potrzeba ośmieliła go do zanoszenia prośby, za której uwzględnienie najuniżeniej dziękuje itp. ${ }^{107}$ Powodów skrępowania E. Bojanowskiego upatrywać należy w barierach stanowych i towarzyskich konwenansach. Było mu bardzo niezręcznie naprzykrzać się przedstawicielce tak znaczącej rodziny arystokratycznej, tym bardziej skoro miała ona stwierdzić, że nie ma aktualnie sumy, jaką bez większych ceregieli płacili inni, znacznie mniej zamożni fundatorzy ochronek. Przedstawiona tu kwestia ilustruje wymownie skomplikowaną sytuację powstającego zgromadzenia, którego materialne utrzymanie oparte było z jednej strony na pracy fizycznej służebniczek, $\mathrm{z}$ drugiej jednak strony niezbędne było uzyskanie znaczącego wsparcia ze strony ziemian w postaci uposażenia powstających ochronek i konieczność częstego odwoływania się do hojności darczyńców.

Fundatorzy ochronki w Rogożewie od pewnego momentu wykazywali słabnące zainteresowanie jej funkcjonowaniem. W 1867 roku Czartoryscy nabyli od hrabiego Józefa Mycielskiego majątek Rokosowo k. Gostynia, gdzie poprzedni właściciel wzniósł kilkanaście lat wcześniej piękną reprezentacyjną siedzibę pałac ucharakteryzowany na zamek obronny ${ }^{108}$. Zamiar pilnego otwarcia ochronki w Rokosowie - nawet gdyby oznaczało to całkowite lub czasowe zamknięcie ochronki w Rogożewie - księżna zakomunikowała E. Bojanowskiemu w styczniu 1868 roku $^{109}$. Nową ochronkę otwarto w marcu 1868 roku, utrzymując jednocześnie tę w Rogożewie ${ }^{110}$. Można domyślać się, dlaczego E. Czartoryskiej zależało na tym, aby ochronka znajdowała się w miejscowości jej aktualnego zamieszkania. Z pośmiertnego wspomnienia wynika, że księżna była osobą znaną ze skłonności do praktykowania działalności dobroczynnej wobec mieszkańców wsi - odwiedzania chat, pomagania chorym, spacerowania z wiejskimi dziećmi,

${ }^{106}$ List E. Bojanowskiego do E. Czartoryskiej z 14.09.1867, w: Korespondencja, t. 1, s. 390-391.

${ }^{107}$ List E. Bojanowskiego do E. Czartoryskiej z 24.09.1867, w: tamże, s. 391.

${ }^{108}$ J. Skuratowicz, Majątki wielkopolskie, t. 1: Powiat gostyński, red. J. Goszczyńska, Szreniawa 1997, s. 135; Dwory polskie w Wielkiem Księstwie Poznańskiem, oprac. L. Durczykiewicz, Poznań 1912, s. 32. O nabyciu przez Czartoryskich majątku Rokosowo pisała ówczesna prasa, opatrując informację charakterystycznym komentarzem: „Cieszy nas bardzo, że tak piękny majątek pozostanie w ręku polskim. Oby i inni nasi kapitaliści, biorąc przykład z księcia Adama Czartoryskiego, chcieli umieszczać kapitały swe w kraju, czy to w ziemi, czy w handlu, czy w innych przedsiębiorstwach, a nie, jak się to często dzieje, składali je w bankach zagranicznych lub więzili po szafach żelaznych”. Wiadomości miejscowe i potoczne, „Dziennik Poznański”, 9 (1867), nr 122, s. 3.

${ }^{109}$ List E. Czartoryskiej do E. Bojanowskiego z 11.01.[18]68, w: Korespondencja, t. 2, s. 15.

${ }^{110}$ Bojanowski, Dziennik, t. 4, s. 231, 234, 243, 256, 259. 
rozdawania książek ${ }^{111}$. Pragnęła zatem, aby ochronka służebniczek znajdowała się w Rokosowie, gdzie mogłaby odwiedzać siostry i ich podopiecznych. Stało się to jednak pośrednio kosztem ochronki w Rogożewie. Poza mniejszym - od czasów przeprowadzki - zainteresowaniem fundatorki, poważnym problemem rogożewskiej ochronki była sytuacja lokalowa. Zabudowania przystosowane na potrzeby ochronki i lazaretu były bowiem w złym stanie technicznym i wymagały ciągłych remontów. Były one na bieżąco i prowizorycznie przeprowadzane, ale ostatecznie księżna zdecydowała, że dalsze funkcjonowanie ochronki w tych warunkach nie ma sensu i w 1869 roku podjęła decyzję ojej zamknięciu ${ }^{112}$. Mieszane odczucia w związku z tą sytuacją miały zapewne pracujące tam siostry, które mimo trudnych warunków wielokrotnie informowały E. Bojanowskiego o dobrych owocach ich posługi w Rogożewie. Rzeczą najbardziej charakterystyczną jest jednak reakcja lokalnej społeczności wiejskiej na zamknięcie przez Czartoryskich tamtejszej ochronki. E. Bojanowski zanotował na ten temat następującą relację: „W Rogożewie Ochronka zamknięta. Lament we wsi wielki, kilka gospodyń pojechało do Księżnej, prosząc o utrzymanie Ochronki, ale dom zbyt zrujnowany, a nowego stawiać nie mogą teraz, więc odmienić nie można"113. Zachowanie mieszkańców wsi, którzy pojechali do księżnej błagać ją, aby nie zamykała ochronki, świadczy o tym, jak potrzebna i pomocna była to wówczas na polskiej wsi instytucja i w jakim stopniu siostry służebniczki potrafiły zjednać sobie wdzięczność i szacunek ludzi, wśród których pracowały.

\section{Stanisław Sczaniecki (Szczaniecki)}

Pojawiający się na kartach prezentowanego listu S. Sczaniecki nie jest związany z poruszaną $\mathrm{w}$ nim tematyką. Został on wymieniony mimochodem przez założyciela służebniczek, informującego o możliwości rychłego kreowania ochronki w Rogożewie, w związku z odłożeniem na później otwarcia ochronki w dobrach Sczanieckiego w Karminie k. Pleszewa. Inauguracja ochronki w dobrach Sczanieckiego wielokrotnie była odkładana. Ostatecznie placówka służebniczek w Karminie nie powstała. Perypetie z powstawaniem tej ochronki są jednym z wielu przykładów trudności i ilości zabiegów towarzyszących powstawaniu tych placówek $^{114}$. Można także przywołać fakt, że rodzina Sczanieckich była poniekąd znacząco związana z biografią założyciela służebniczek, bowiem brat Stanisława Konstanty Sczaniecki - został wymieniony w testamencie E. Bojanowskiego jako główny beneficjent spadku po nim ${ }^{115}$.

${ }^{111}$ Karwowski, Historja Wielkiego Księstwa, t. 3, s. 74.

${ }^{112}$ Zgoła inaczej przedstawiała się natomiast sytuacja w Rokosowie, gdzie ochronka powstała w nowym budynku, specjalnie w tym celu postawionym jeszcze przez wcześniejszego właściciela. Zamknięcie ochronki w Rogożewie nastąpiło w maju 1869 roku. Zgodnie z regułą służebniczek wymagało to formalnych decyzji siostry przełożonej i komisarza duchownego ks. J. Koźmiana. Bojanowski, Dziennik, t. 4, s. 115, 132, 231, 472, 474.

${ }^{113}$ Tamże, t. 4, s. 480.

${ }^{114}$ Tamże, t. 3, s. 642, 690, 691, 693, 697, 701, 705, 709, 710, 721, 764, 768; t. 4, s. 61, 67, 75.

${ }^{115}$ Chodziło o 2 tysiące talarów ze sprzedaży gospodarstwa Boreczek w Koszkowie, przeznaczone na spłatę długu przyrodniego brata E. Bojanowskiego - Teofila Wilkońskiego. Kornacka, Edmund Bojanowski, s. 140. 


\section{BIBLIOGRAFIA}

\section{Źródla}

\section{Archiwum Archidiecezjalne w Poznaniu (AAP)}

Akta Konsystorza Generalnego Arcybiskupiego Poznańskiego, sygn. KA 1061, Personalia kleryka Antoniego Smitkowskiego.

\section{Wydawnictwa zwarte}

Bojanowski Edmund, Dziennik, wydanie kompletne rękopisu i luźnych kartek Dziennika wraz z zapisami dziennymi Ochronka Podrzecka 1851-1854 i relacją s. Elżbiety Szkudłapskiej Ostatnie dnie życia $i$ pogrzeb, objaśnił, skomentował i wstępem poprzedził L. Smołka, t. 1-4, Wrocław 2009.

Bojanowski Edmund, Korespondencja Edmunda Bojanowskiego z lat 1829-1871, t. 1: Listy Edmunda Bojanowskiego z lat 1836-1871, t. 2: Listy do Edmunda Bojanowskiego z lat 1829-1868, objaśnił, skomentował i zarysem monograficznym poprzedził L. Smołka, Wrocław 2001.

„Dziennik Poznański” 1867, 1871.

Elenchus universi cleri Archidioec. Posnaniensis pro Anno Domini..., w: Ordo Officii Divini ad usum Almae Eccles. Metropolitanae et Archi-Dioec. Posnaniensis pro Anno Domini..., Posnaniae (lata 1847-1872).

Likowski Edward X., Mowa żałobna na cześć śp. Xięcia Adama Konstantego Czartoryskiego zmartego $w$ Rokosowie dnia 19 grudnia 1880 roku powiedziana w kościele parafialnym krobskim na nabożeństwie żałobnem dnia 23 grudnia, Poznań (b.d.).

Motty Marceli, Przechadzki po mieście (poznaniu), oprac. i wstępem opatrzył Z. Grot, przypisy przeredagował i uzupełnił W. Molik, t. 2, Poznań 1999.

\section{Opracowania}

Absolwenci Gimnazjum i Liceum Świętej Marii Magdaleny w Poznaniu 1805-1950, oprac. A. Białobłocki, Poznań 1995.

Biesiada Jacek, Ksiądz Symforian Tomicki - pisarz, redaktor „Szkółki Niedzielnej” $i$,,Oświaty”, „Ecclesia. Studia z Dziejów Wielkopolski”, 9 (2014) s. 153-185.

Dwory polskie w Wielkiem Księstwie Poznańskiem, oprac. L. Durczykiewicz, Poznań 1912.

Górski Adam, Dokumenty z wieży kościoła w Przybymierzu, „Studia Zachodnie”, 8 (2006) S. 283-298.

Karwowski Stanisław, Historja Wielkiego Księstwa Poznańskiego, t. 3: 1890-1914, Poznań 1931.

Kornacka Maria Manfreda, Edmund Bojanowski (1814-1871), „Nasza Przeszłość. Studia z dziejów Kościoła i kultury katolickiej w Polsce”, 26 (1967) s. 5-145.

Krzyżosiak Romuald, Z dziejów parafii rzymskokatolickiej w Jutrosinie. 100 lat istnienia obecnego kościoła parafialnego, Jutrosin 2002.

Krzyżosiak Romuald, Kościót św. Elżbiety w Jutrosinie na tle historii parafii jutrosińskiej, Jutrosin 2008.

Kukiel Marian, Czartoryski Adam Konstanty, w: Polski słownik biograficzny, t. 4, Kraków 1938.

Kwilecki Andrzej, Ziemiaństwo wielkopolskie, Warszawa 1998.

Kwilecki Andrzej (red.), Czartoryscy herbu Pogoń litewska, w: Ziemiaństwo wielkopolskie. W kregu arystokracji, Poznań 2004, s. 326-380. 
Kwilecki Andrzej, Wielkopolskie rody ziemiańskie, Poznań 2010.

Molik Witold, (rec.) Korespondencja bt. Edmunda Bojanowskiego, „Kronika Wielkopolski”, (2003) nr 1, s. 119-121.

Moryson Jakub, Książę Olgierd Czartoryski (1888-1977). Życie i działalność społecznopolityczna, Kraków 2012.

Rzepecki Ludwik, Obraz katolickich szkót elementarnych objętych Archidyjecezyjami Gnieźnieńska i Poznańska oraz Dyjecezyjami Chetmińska i Warmińska, Poznań 1867.

Skuratowicz Jan, Majątki wielkopolskie, t. 1: Powiat gostyński, red. J. Goszczyńska, Szreniawa 1997.

Smołka Leonard, Edmund Bojanowski $i$ jego korespondencja z lat 1829-1871, w: Korespondencja Edmunda Bojanowskiego z lat 1829-1871, t. 1, objaśnił, skomentował i zarysem monograficznym poprzedził L. Smołka, Wrocław 2001, s. 5-108.

Zając Paweł, Misje jezuitów w Wielkopolsce $i$ ich obrzańska rezydencja $w$ latach 18521855, „Ecclesia. Studia z Dziejów Wielkopolski”, 9 (2014) s. 187-222.

Załęski Stanisław, Jezuici w Polsce, t. 5: Jezuici w Polsce porozbiorowej 1773-1905, cz. 2: 1820-1905, Kraków 1906.

Zieliński Zygmunt, Kościół katolicki w Wielkim Księstwie Poznańskim w latach 18481865, Lublin 1973.

Żychliński Teodor, Kronika żałobna rodzin wielkopolskichod 1863-1876r.zuwzględnieniem ważniejszych osobistości zmartych w tym przeciagu czasu w innych dzielnicach Polski i na obczyźnie, Poznań 1877.

Żychliński Teodor, Złota księga szlachty polskiéj, t. 8, Poznań 1886.

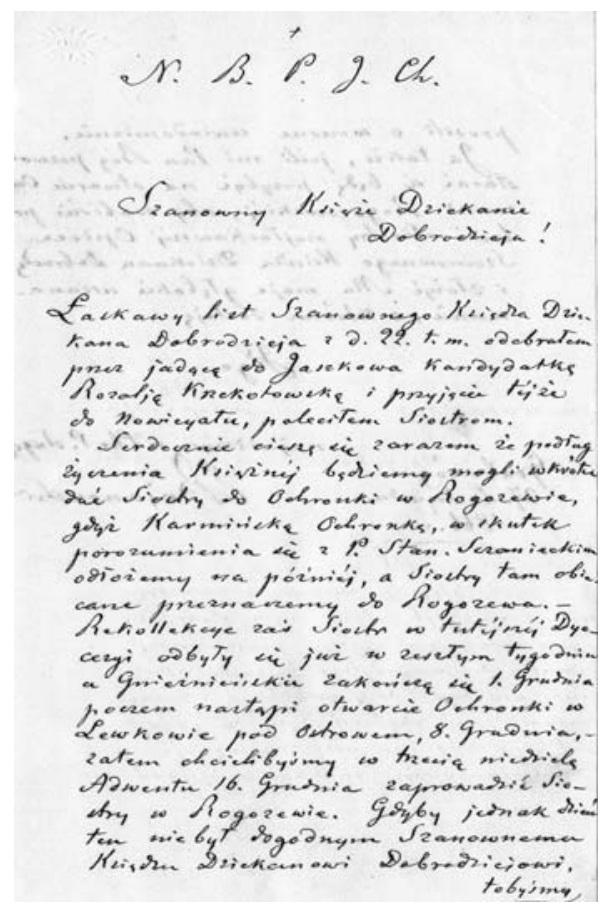

Il.1. Rękopis listu 


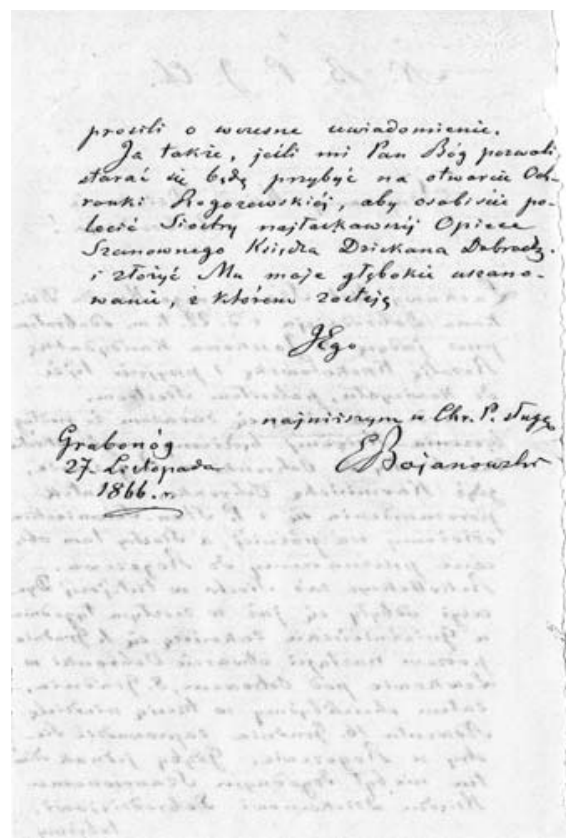

Il.2. Rękopis listu

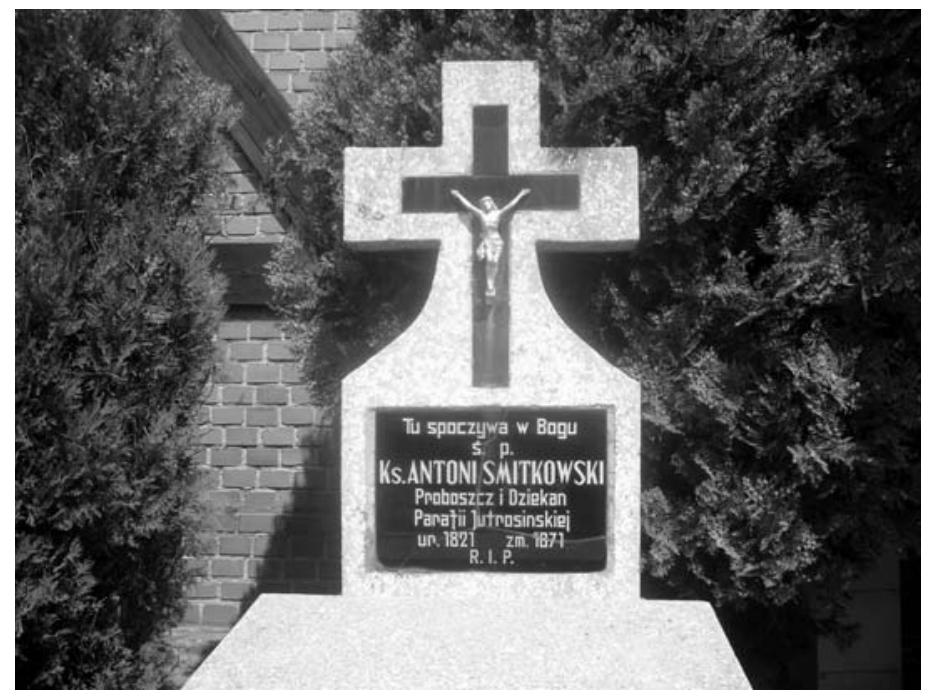

I1.3. Nagrobek ks. Antoniego Śmitkowskiego na cmentarzu w Jutrosinie przy kościele pw. Świętego Krzyża. Nazwisko kapłana zapisano w starszej wersji „Smitkowski”. Popełniono też błąd w dacie urodzenia - powinno być 1820 (fot. autora). 


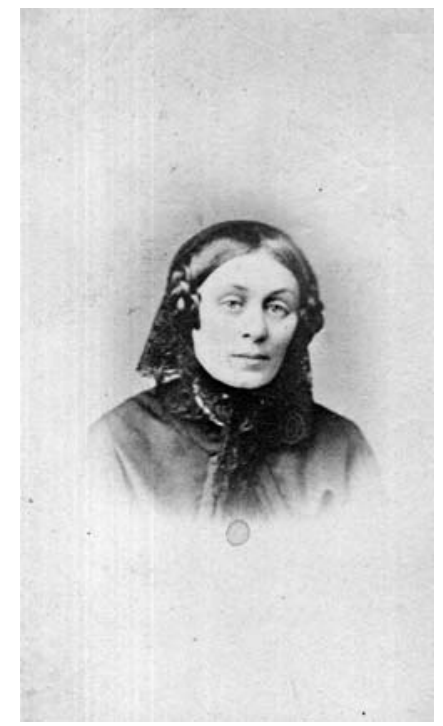

Il.4. Księżna Elżbieta z Działyńskich Czartoryska

(fot. Muzeum Tatrzańskie im. Dra Tytusa Chałubińskiego w Zakopanem)

\title{
EDMUND BOJANOWSKI'S UNKNOWN LETTER FROM A PRIVATE COLLECTION
}

\begin{abstract}
Summary
Doing the research on E. Bojanowski's scholarly achievements, the author of the article came across Bojanowski's unknown letter of 1866. The correspondence was accompanied by an extensive comment on its historical context. First of all, the bibliography of the letter recipient (Rev. Antoni Śmitkowski) is presented. The article also describes the cooperation between the founder of the Sister Servants and the founder of the orphanage (its opening is discussed in the correspondence) - the Duchess Elżbieta Czartoryska née Działyńska. In addition, the author traces the recruitment process of the candidates for the congregation of the Sister Servants illustrated with the example of Rozalia Krzekotowska mentioned in the correspondence.
\end{abstract}

Key words: Edmund Bojanowski; Elżbieta Czartoryska née Działyńska; Rev. Antoni Śmitkowski; correspondence; rural orphanages 